\title{
The role of serotonin in memory: interactions with neurotransmitters and downstream signaling
}

\author{
Mohammad Seyedabadi · Gohar Fakhfouri · \\ Vahid Ramezani · Shahram Ejtemaei Mehr • \\ Reza Rahimian
}

Received: 28 April 2013 / Accepted: 20 December 2013 / Published online: 16 January 2014

(C) Springer-Verlag Berlin Heidelberg 2014

\begin{abstract}
Serotonin, or 5-hydroxytryptamine (5-HT), is found to be involved in many physiological or pathophysiological processes including cognitive function. Seven distinct receptors (5- $\left.\mathrm{HT}_{1-7}\right)$, each with several subpopulations, have been identified for serotonin, which are different in terms of localization and downstream signaling. Because of the development of selective agonists and antagonists for these receptors as well as transgenic animal models of cognitive disorders, our understanding of the role of serotonergic transmission in learning and memory has improved in recent years. A large body of evidence indicates the interplay between serotonergic transmission and other neurotransmitters including acetylcholine, dopamine, $\gamma$-aminobutyric acid (GABA) and glutamate, in the neurobiological control of learning and memory. In addition,
\end{abstract}

M. Seyedabadi

Department of Molecular Imaging, The Persian Gulf Biomedical

Sciences Research Institute, Bushehr University of Medical

Sciences, Bushehr, Iran

G. Fakhfouri

Department of Psychiatry and Neuroscience, Université Laval,

Quebec, QC, Canada

G. Fakhfouri

Institut Universitaire en Santé Mentale de Québec (IUSMQ)

Research Center, Quebec, QC, Canada

V. Ramezani

Department of Pharmaceutics, Faculty of Pharmacy, Shahid

Sadoughi University of Medical Sciences, Yazd, Iran

S. E. Mehr $\cdot$ R. Rahimian $(\bowtie)$

Department of Pharmacology, School of Medicine, Tehran

University of Medical Sciences, P. O. Box 13145-784,

Tehran, Iran

e-mail: rahimian78@gmail.com there has been an alteration in the density of serotonergic receptors in aging and Alzheimer's disease, and serotonin modulators are found to alter the process of amyloidogenesis and exert cognitive-enhancing properties. Here, we discuss the serotonin-induced modulation of various systems involved in mnesic function including cholinergic, dopaminergic, GABAergic, glutamatergic transmissions as well as amyloidogenesis and intracellular pathways.

Keywords Serotonin $\cdot$ Memory $\cdot$ Signaling pathways

$\begin{array}{ll}\text { Abbreviations } \\ \text { 2PSDT } & \text { Two-platform spatial discrimination task } \\ \text { 3xTg-AD } & \begin{array}{l}\text { Triple-transgenic mouse model of Alzheimer's } \\ \text { disease }\end{array} \\ \text { 5-HT } & \text { 5-Hydroxytryptamine } \\ \text { AC } & \text { Adenylate cyclase } \\ \text { Ach } & \text { Acetylcholine } \\ \text { AD } & \text { Alzheimer's disease } \\ \text { APP } & \text { Amyloid precursor protein } \\ \text { ARN } & \text { Anterior raphe nucleus } \\ \text { A } \beta & \text { Amyloid } \beta \\ \text { cAMP } & \text { Cyclic adenosine monophosphate } \\ \text { cGMP } & \text { Cyclic guanosine monophosphate } \\ \text { CPP } & \text { Conditioned place preference } \\ \text { CREB } & \text { cAMP-response element binding } \\ \text { DA } & \text { Dopamine } \\ \text { DH } & \text { Dorsal hippocampus } \\ \text { DMTS } & \text { Delayed matching to sample } \\ \text { DNPTP } & \text { Delayed non-matching to position } \\ \text { DRN } & \text { Dorsal raphe nucleus } \\ \text { EPAC } & \text { Exchange proteins activated by cAMP } \\ \text { EPSCs } & \text { Excitatory postsynaptic currents } \\ \text { ERK } & \text { Extracellular signal-regulated kinase } \\ \text { FC } & \text { Frontal cortex }\end{array}$




$\begin{array}{ll}\text { GABA } & \text { Gamma }(\gamma) \text {-aminobutyric acid } \\ \text { GAD } & \text { Glutamic acid decarboxylase } \\ \mathrm{G}_{\mathrm{i}} & \text { Inhibitory G-protein } \\ \text { Glu } & \text { Glutamate } \\ \text { GPCRs } & \text { G-protein-coupled receptors } \\ \text { Gs } & \text { Stimulatory G-protein } \\ \text { GSK3 } & \text { Glycogen synthase kinase } 3 \\ \text { i.c.v. } & \text { Intracerebroventricular } \\ \text { i.p. } & \text { Intraperitoneal } \\ \text { i.v. } & \text { Intravenous } \\ \text { LTP } & \text { Long-term potentiation } \\ \text { LTD } & \text { Long-term depression } \\ \text { MAPK } & \text { Mitogen-activated protein kinases } \\ \text { MBN } & \text { Magnocellular nucleus basalis } \\ \text { mGluR } & \text { Metabotropic glutamate receptor } \\ \text { MS/vDB } & \text { Medial septum and the adjacent vertical limb } \\ & \text { of the diagonal band of Broca area } \\ \text { MWM } & \text { Morris water maze } \\ \text { NAc } & \text { Nucleus accumbens } \\ \text { NMDA } & \text { N-Methyl-D-aspartate } \\ \text { NO } & \text { Nitric oxide } \\ \text { ORT } & \text { Object recognition task } \\ \text { PA } & \text { Passive avoidance } \\ \text { PCA } & \text { p-Chloroamphetamine } \\ \text { PDE } & \text { Phosphodiesterase } \\ \text { PFC } & \text { Prefrontal cortex } \\ \text { PI } & \text { Pavlovian/instrumental autoshaping } \\ \text { PKA } & \text { Protein kinase A } \\ \text { PKC } & \text { Protein kinase C } \\ \text { PKG } & \text { Protein kinase G } \\ \text { PKM } & \text { Protein kinase M } \\ \text { PLA2 } & \text { Phospholipase A2 } \\ \text { PS1 } & \text { Presenilin-1 } \\ \text { PT } & \text { Pass through } \\ \text { s.c. } & \text { Subcutaneous } \\ \text { SA } & \text { Self-administration } \\ \text { sIPSC } & \text { Spontaneous inhibitory postsynaptic current } \\ \text { VTA } & \text { Ventral tegmental area } \\ & \end{array}$

\section{Introduction}

Serotonin, or 5-hydroxytryptamine (5-HT), plays a pivotal role in the cognitive function, and serotonin modulators are indicated for the treatment of an array of psychiatric disorders (Boulougouris and Tsaltas 2008; Kiser et al. 2012; Meltzer et al. 2012). A large body of evidence implicates the contribution of various serotonin receptors in mnesic function (Perez-Garcia and Meneses 2008b; Geldenhuys and Van der Schyf 2009), though an interplay between serotonin and several other neurotransmitters including acetylcholine (Ach), dopamine (DA), glutamate (Glu) and $\gamma$-aminobutyric acid (GABA) is found to be involved in a variety of neurophysiological processes including learning and memory (Nic Dhonnchadha and Cunningham 2008; Kranz et al. 2010; Lesch and Waider 2012).

Seven distinct families of serotonin receptors with several subpopulations have been identified which differ in terms of localization and downstream signaling (Barnes and Sharp 1999; Hoyer et al. 2002). Except for the 5-HT 3 receptors that are ligand-gated ion channels, the rest belong to the family of G-protein-coupled receptors (GPCRs); in this regard, $5-\mathrm{HT}_{1}$ and $5-\mathrm{HT}_{5}$ receptors are coupled to inhibitory G-protein $\left(\mathrm{G}_{\mathrm{i}}\right)$, whereas 5- $\mathrm{HT}_{4}, 5-\mathrm{HT}_{6}$ and 5- $\mathrm{HT}_{7}$ receptors are connected to the stimulatory G-protein $\left(\mathrm{G}_{\mathrm{s}}\right)$, and 5- $\mathrm{HT}_{2}$ receptors activate $\mathrm{G}_{\mathrm{q} / 11}$ (Pytliak et al. 2011).

Several imaging experiments have revealed a profound alteration in the density of serotonergic receptors in aging and Alzheimer's disease (AD) (Rodriguez et al. 2012). Furthermore, some of the serotonin modulators are found to change the expression or processing of amyloid precursor protein (APP) (Payton et al. 2003; Postina 2012). Therefore, to elucidate the role of serotonin in memory, it is crucial to clarify the detailed interactions with other neurotransmitters and second messengers related with mnemonic or amnestic effects.

Here, we review the serotonin-induced modulation of cholinergic, dopaminergic, GABAergic and glutamatergic systems regarding their effects on learning and memory. In addition, we discuss the serotonergic modulation of amyloidogenesis as well as the intracellular pathways through which serotonin influences mnesic function.

The effects of serotonin on cholinergic transmission

Early studies demonstrated that both serotonin and acetylcholine enhance performance in one-trial inhibitory avoidance task. Moreover, co-administration of the serotonin reuptake inhibitor (alaproclate) and cholinergic agonist (oxotremorine) produces synergistic effects on memory retrieval. Cholinergic blockade reverses the facilitation caused by either this co-administration or cholinergic activation, but not that caused by serotonergic stimulation (Altman et al. 1987). In addition, transplantation of embryonic raphe cells into the hippocampus can improve the impairment of spatial memory caused by a combination of serotonergic/cholinergic deficiencies (Richter-Levin and Segal 1989). Intrahippocampal grafts of mixed septal-raphe cell suspension restore the reduction in Ach concentration due to aspirative fimbria-fornix lesions. This effect is recapitulated by septal grafts but to a lower extent, suggesting a functional interaction between serotonergic raphe and cholinergic septal neurons (Hilgert et al. 2000).

$5-\mathrm{HT}_{1 \mathrm{~A}}$ receptors $\left(5-\mathrm{HT}_{1 \mathrm{~A}} \mathrm{R}\right)$ are co-expressed with cholinergic markers on medial septum and diagonal band of Broca. However, the proportion of neurons expressing 
both markers vary in dorsal, ventral or septal regions (Kia et al. 1996). Blockade of the postsynaptic $5-\mathrm{HT}_{1 \mathrm{~A}}$ receptors by NAN-190 or WAY 100635 can ameliorate the scopolamine-induced impairment of working memory and spatial learning in passive avoidance (PA) (Misane and Ogren 2003), object recognition task (ORT) (Pitsikas et al. 2003), pass through (PT) (Ohno and Watanabe 1996) or in twoplatform spatial discrimination task (2PSDT) (Carli et al. 1997a). In contrast, stimulation of the presynaptic $5-\mathrm{HT}_{1 \mathrm{~A}} \mathrm{R}$ in dorsal raphe nucleus (DRN) by 8-OH-DPAT corrects the errors in choice accuracy caused by intrahippocampal administration of scopolamine (Carli et al. 1998). Moreover, injection of WAY 100635 into DRN neither altered choice accuracy nor affected the scopolamine-induced errors, but it did reverse the 8-OH-DPAT mitigation of deficits due to scopolamine (Carli et al. 2000). A combined sigma/5- $\mathrm{HT}_{1 \mathrm{~A}}$ receptors agonist, OPC-14523, reverses scopolamine- and age-associated learning and memory deficits in passive avoidance or Morris water maze (MWM) (Tottori et al. 2002). These effects might be mediated by an increase in ACh release in dorsal hippocampus (DH; Tottori et al. 2002), although some studies demonstrated that noncholinergic neurons might play the main role in serotonin effects on hippocampal memory processing (Koenig et al. 2011). Subcutaneous (s.c.) administration of $5-\mathrm{HT}_{1 \mathrm{~B}}$ receptor $\left(5-\mathrm{HT}_{1 \mathrm{~B}} \mathrm{R}\right)$ agonists impairs memory retention in onetrial PA. Furthermore, the $5-\mathrm{HT}_{1 \mathrm{~B}} \mathrm{R}$ antagonist, NAS-181, improves performance in PA test in a dose-dependent manner and reverses memory deficit induced by scopolamine (when administered prior, but not after, scopolamine) or MK-801, N-Methyl-D-aspartate (NMDA) receptor antagonist. This effect might be explained by the inhibitory effect of these heteroreceptors on cholinergic or glutamatergic neurons (Eriksson et al. 2008).

It has been shown that both p-chloroamphetamine (PCA, a serotonin releaser) and scopolamine impair the retrieval of electric shock avoidance in the step-down test (Matsuno et al. 1993). In addition, the 5- $\mathrm{HT}_{2}$ receptor $\left(5-\mathrm{HT}_{2} \mathrm{R}\right)$ antagonists, ritanserin and mianserin, ameliorate the deficit caused by PCA but not that induced by scopolamine. In contrast, cholinomimetic agents offset both PCA- and scopolamine-induced amnesia (Matsuno et al. 1993), suggesting that cholinergic transmission might be downstream to $5-\mathrm{HT}_{2} \mathrm{R}$ signaling.

The 5- $\mathrm{HT}_{3}$ receptor $\left(5-\mathrm{HT}_{3} \mathrm{R}\right)$ antagonists, Y-25130 (Ohno and Watanabe 1997), DAU 6215 (also known as Itasetron) (Brambilla et al. 1993), ICS 205930 (also known as tropisetron) (Chugh et al. 1991) and ondansetron (Carli et al. 1997b), reverse the scopolamine-induced learning and memory deficit in different paradigms including step-through passive avoidance, dark chamber aversion or two-platform spatial discrimination task. Although less effective than direct nicotinic or muscarinic agonists, the
5-HT ${ }_{3} \mathrm{R}$ antagonist, WAY100289, was shown to ameliorate the impairment of spatial learning caused by lesions to the cholinergic projections in nucleus basalis and medial septal brain regions (Hodges et al. 1995). The 5- $\mathrm{HT}_{3} \mathrm{R}$ antagonist, RS-56812, was also reported to improve performance in delayed matching to sample (DMTS) task in monkeys (Terry et al. 1996). On the other hand, 5- $\mathrm{HT}_{3} \mathrm{R}$ antagonist, ondansetron, failed to attenuate scopolamine-induced impairments in episodic memory and processing speed in healthy volunteers (Broocks et al. 1998).

In vitro experiments revealed that $5-\mathrm{HT}_{4}$ receptor $\left(5-\mathrm{HT}_{4} \mathrm{R}\right)$ activation augmented $[3 \mathrm{H}]$ choline efflux in electrically stimulated slices of cerebral cortex, hippocampus and nucleus basalis magnocellularis; however, it did not alter $[3 \mathrm{H}]$ choline efflux in resting brain slices (Siniscalchi et al. 1999). Likewise, intracerebroventricular (i.c.v) administration of the $5-\mathrm{HT}_{4} \mathrm{R}$ agonists augmented $\mathrm{ACh}$ release in the frontal cortex (FC) but not in the striatum or DH (Consolo et al. 1994). Moreover, 5-HT 4 receptor blockade does not affect Ach release, but prevents the facilitatory effect of agonists suggesting the lack of constitutive activity (Consolo et al. 1994). It is also shown that $5-\mathrm{HT}_{4} \mathrm{R}$ agonists, BIMU 1 and RS 67333, recover scopolamine-induced impairment of performance in Y-maze (Lelong et al. 2003). The 5- $\mathrm{HT}_{4} \mathrm{R}$ knockout mice display similar spatial learning as well as short- and long-term retention to wild type in MWM. However, they are more sensitive to scopolamineinduced memory deficit, and show less choline acetyltransferase (ChAT) activity in the septum and the DH (Segu et al. 2010). The facilitatory effect of $5-\mathrm{HT}_{4} \mathrm{R}$ agonist, SC 53116, on spike amplitude and tetanus-induced long-term potentiation (LTP) in the hippocampal CA1 is also blocked by scopolamine in electrophysiological experiments (Matsumoto et al. 2001).

The 5- $\mathrm{HT}_{6}$ receptor $\left(5-\mathrm{HT}_{6} \mathrm{R}\right)$ antagonist, SB-271046, does not influence working memory, aversive learning or recognition memory (Da Silva et al. 2012). However Ro 046790 or SB $271046,5-\mathrm{HT}_{6} \mathrm{R}$ antagonists, reverse the scopolamine- or age- induced defect in novel object discrimination task (Woolley et al. 2003), PA (Foley et al. 2004; Da Silva et al. 2012), working memory (spontaneous alternation task in the T-maze) and conditioned emotion response (Da Silva et al. 2012), and partially alter scopolamine impaired recognition memory (Da Silva et al. 2012).

The 5- $\mathrm{HT}_{7}$ receptor $\left(5-\mathrm{HT}_{7} \mathrm{R}\right)$ agonist, AS 19, enhances memory formation in autoshaping Pavlovian/instrumental (PI) learning task. This facilitatory effect is blocked by SB-269970, the $5-\mathrm{HT}_{7} \mathrm{R}$ antagonist, but not by WAY100635, 5- $\mathrm{HT}_{1 \mathrm{~A}} \mathrm{R}$ antagonist (Perez-Garcia and Meneses 2005). In addition, AS 19 reverses memory deficit due to scopolamine (cholinergic antagonist) or dizocilpine (NMDA antagonist) (Perez-Garcia and Meneses 2005), 
whereas SB269970 augments scopolamine-induced impairment in delayed non-matching to position (DNPTP) task (Bonaventure et al. 2011). In contrast, 5- $\mathrm{HT}_{7} \mathrm{R}$ antagonists, SB-269970 and DR 4004, abrogate memory impairment due to scopolamine or dizocilpine in autoshaping PI learning task (Meneses 2004). This controversy may arise from the differences in scopolamine dose, strains of rats, the forms of memory (consolidation or working) and the protocol used in PI and DNPTP tests (Bonaventure et al. 2011).

The alpha7 nicotinic acetylcholine receptor $(\alpha 7 \mathrm{nAChR})$ has been associated with cognitive function as well as anxiety (Toyohara and Hashimoto 2010; Pandya and Yakel 2013). Serotonin denervation of the rat prefrontal cortex (PFC) by a chemical lesion in the anteroventral DRN changed the pattern of expression of nicotinic cholinoceptors, while $\alpha 4$ receptors were overexpressed, $\alpha 7 \mathrm{nAChR}$ underwent a significant decrease in denervated rats (Soria-Fregozo et al. 2013). Moreover, the 5-HT $1 \mathrm{~A}$ receptor antagonist, WAY-100135, blocked the anxiogenic effects of activation of the $\alpha 7 \mathrm{nAChR}$ (Pandya and Yakel 2013). A novel $\alpha 7 n A C h R$ agonist/5$\mathrm{HT}_{3} \mathrm{R}$ antagonist, EVP-5141, restored scopolamine- or ageinduced impairment of memory acquisition and retention in the PA task or spatial working memory in water maze. Moreover, EVP-5141 improved both objective and social recognition memory and was not substituted for nicotine in rats trained to discriminate nicotine from saline, suggesting less potential for abuse (Boess et al. 2013).

In summary, stimulation of the $5-\mathrm{HT}_{7}$ receptors as well as blockade of $5-\mathrm{HT}_{3}, 5-\mathrm{HT}_{4}$ and $5-\mathrm{HT}_{6}$ receptors seems to recover scopolamine-induced memory impairment in a variety of experiments. The effects of $5-\mathrm{HT}_{1 \mathrm{~A}}$ ligands depend on the activation of pre- or postsynaptic neurons. In contrast, the 5- $\mathrm{HT}_{1 \mathrm{~B}}$ agonists impair memory retention possibly through an inhibitory effect on cholinergic or glutamatergic neurons. The $\alpha 7 \mathrm{nAChR}$ agonist $/ 5-\mathrm{HT}_{3} \mathrm{R}$ antagonist has also been shown to produce positive effects on both scopolamine- or age-induced memory impairment (Table 1).

\section{The effects of serotonin on dopaminergic transmission}

The mesocortical dopaminergic pathway is pivotal to the complex cognitive processes including selective attention and working memory. Likewise, the mesolimbic dopaminergic pathway is prominent in drug-induced reward and addiction memory (Wise and Rompre 1989; Nic Dhonnchadha and Cunningham 2008).

It has been shown that $5-\mathrm{HT}_{1 \mathrm{~A}}$ receptors may increase or decrease mesolimbic neural firing depending on the activation of either pre- or postsynaptic receptors (Carey et al. 2004; Andrews et al. 2005). Moreover, hormesis (low-dose stimulation, high-dose inhibition) has been demonstrated for the alteration in DA concentration in PFC by $5-\mathrm{HT}_{1 \mathrm{~A}} \mathrm{R}$ agonists (Diaz-Mataix et al. 2005). Both blockade of preand stimulation of postsynaptic 5-HT $\mathrm{HA}_{1 \mathrm{~A}}$ receptors augment cocaine-stimulated DA release and hyperlocomotion (Carey et al. 2004; Andrews et al. 2005). In addition, the 5-HT ${ }_{1 \mathrm{~A}} \mathrm{R}$ antagonist, WAY 100635, attenuates cocaine- but not cueprimed reinstatement of cocaine self-administration (SA) (Burmeister et al. 2004). The 5- $\mathrm{HT}_{1 \mathrm{~B}} \mathrm{R}$ agonists enhance cocaine-induced conditioned place preference (CPP) and SA (Parsons et al. 1998; Cervo et al. 2002). However, RU24969, 5- $\mathrm{HT}_{1 \mathrm{~B} / 1 \mathrm{~A}}$ agonist, interferes with the retrieval of cocaine- or sucrose-seeking response following extinction. These effects are blocked by GR127935, the 5- $\mathrm{HT}_{1 \mathrm{~B}}$ $R$ antagonist (Acosta et al. 2005). In this regard, 5-HT ${ }_{1 B} R$ antagonism decreases cocaine-induced DA release and prevents its reinforcing effects (O'Dell and Parsons 2004). This suggests that blockade of the $5-\mathrm{HT}_{1 \mathrm{~B}}$ receptors may inhibit reinforcement as well as memory formation due to drugs of abuse, while agonists at this receptor might help decrease the craving during abstinence and relapse.

The activation of 5- $\mathrm{HT}_{2 \mathrm{~A}}$ receptors $\left(5-\mathrm{HT}_{2 \mathrm{~A}} \mathrm{R}\right)$ enhances dopaminergic activity both in nigrostriatal and in corticomesolimbic pathways (Alex and Pehek 2007) possibly through glutamatergic neurons (Kalivas et al. 1989; Kalivas 1993). The 5- $\mathrm{HT}_{2 \mathrm{~A}} \mathrm{R}$ antagonist, M100907, suppresses cueinduced reinstatement of cocaine SA and retrieval of addiction-primed memories following extinction (Nic Dhonnchadha et al. 2009). The 5- $\mathrm{HT}_{2 \mathrm{C}} \mathrm{R}$ inverse agonists or antagonists boost cocaine-mediated DA release in nucleus accumbens (NAc) and hyperlocomotion (Filip and Cunningham 2003; Navailles et al. 2004). Likewise, injection of Ro60-0175, the 5- $\mathrm{HT}_{2 \mathrm{C}} \mathrm{R}$ agonist, into the ventral tegmental area (VTA) diminishes cocaine SA and hyperlocomotion (Fletcher et al. 2004). Moreover, $5-\mathrm{HT}_{2 \mathrm{C}} \mathrm{R}$ agonists decrease contextual cue, cocaine or yohimbine-primed lever response and reinstatement of cocaine-seeking behavior after extinction training (Neisewander and Acosta 2007; Fletcher et al. 2008). These observations suggest that inhibition of $5-\mathrm{HT}_{2 \mathrm{~A}} \mathrm{R}$ and stimulation of $5-\mathrm{HT}_{2 \mathrm{C}} \mathrm{R}$ hamper memory formation and retrieval in addiction, and should be considered as potential interventions to decrease craving for drugs of abuse (Nic Dhonnchadha and Cunningham 2008).

The stimulation of $5-\mathrm{HT}_{3}$ receptors leads to the depolarization of host cells. These receptors are expressed presynaptic on dopaminergic terminals (Chen et al. 1992), and may increase DA release in the NAc (Jiang et al. 1990). Furthermore, antagonists of this receptor are shown to attenuate morphine-, ethanol-, nicotine- or cocaine-stimulated DA release in the NAc as well as their rewarding effects (Carboni et al. 1989; Imperato and Angelucci 1989; Grant and Barrett 1991; Pei et al. 1993; Campbell and McBride 1995; Rodd-Henricks et al. 2003; 
Table 1 Interactions between serotonergic and cholinergic pathways in memory

\begin{tabular}{|c|c|c|c|c|c|}
\hline \multirow[t]{2}{*}{ Receptors } & \multicolumn{2}{|l|}{ Ligand } & \multirow[t]{2}{*}{ Test } & \multirow{2}{*}{$\begin{array}{l}\text { Effect on memory } \\
\text { impairment due to } \\
\text { cholinergic blockade } \\
\text { or lesions }\end{array}$} & \multirow[t]{2}{*}{ References } \\
\hline & Agonists & Antagonists & & & \\
\hline \multirow[t]{7}{*}{$5-\mathrm{HT}_{1 \mathrm{~A}}$} & OPC- $14523^{\mathrm{a}}$ (oral) & & MWM \& PA & Improvement & Tottori et al. (2002) \\
\hline & $\begin{array}{l}\text { 8-OH-DPAT (dorsal } \\
\text { raphe) }\end{array}$ & & 2PSD & Improvement & Carli et al. (1998) \\
\hline & & $\begin{array}{l}\text { NAN-190 (s.c.), WAY } \\
100635 \text { (s.c.) }\end{array}$ & PA & Improvement & $\begin{array}{l}\text { Misane and Ogren } \\
\text { (2003) }\end{array}$ \\
\hline & & WAY 100635 (s.c.) & ORT & Improvement & Pitsikas et al. (2003) \\
\hline & & $\begin{array}{l}\text { NAN-190 (intrahip- } \\
\text { pocampal) }\end{array}$ & PT & Improvement & $\begin{array}{l}\text { Ohno and Watanabe } \\
\text { (1996) }\end{array}$ \\
\hline & & WAY 100635 (s.c.) & 2PSD & Improvement & Carli et al. (1997a) \\
\hline & & $\begin{array}{l}\text { WAY } 100635 \text { (dorsal } \\
\text { raphe) }\end{array}$ & 2PSD & No effect & Carli et al. (2000) \\
\hline $5-\mathrm{HT}_{1 \mathrm{~B}}$ & & NAS-181 (s.c.) & PA & Improvement $^{\mathrm{b}}$ & Eriksson et al. (2008) \\
\hline $5-\mathrm{HT}_{2}$ & & $\begin{array}{l}\text { Ritanserin and mian- } \\
\text { serin }\end{array}$ & PA & No effect & Matsuno et al. (1993) \\
\hline \multirow[t]{6}{*}{$5-\mathrm{HT}_{3}$} & & $\begin{array}{l}\text { Y-25130 (intrahip- } \\
\text { pocampal) }\end{array}$ & PT & Improvement & $\begin{array}{l}\text { Ohno and Watanabe } \\
\text { (1997) }\end{array}$ \\
\hline & & DAU 6215 (i.p.) & PA and hypermotility & Improvement & Brambilla et al. (1993) \\
\hline & & ICS 205-930 (s.c.) & PA & Improvement & Chugh et al. (1991) \\
\hline & & Ondansetron (s.c.) & 2PSD & improvement & Carli et al. (1997b) \\
\hline & & WAY100289 (s.c.) & MWM & Improvement & Hodges et al. (1995) \\
\hline & & Ondansetron (iv) ${ }^{\mathrm{c}}$ & $\begin{array}{l}\text { Word, target, distance } \\
\text { recall }\end{array}$ & No effect & Broocks et al. (1998) \\
\hline \multirow[t]{2}{*}{$5-\mathrm{HT}_{4}$} & $\begin{array}{l}\text { BIMU } 1 \text { and RS } \\
67333 \text { (i.p.) }\end{array}$ & & Y-maze & Improvement & Lelong et al. (2003) \\
\hline & SC 53116 (i.c.v.) & & PA & Improvement & $\begin{array}{l}\text { Matsumoto et al. } \\
\text { (2001) }\end{array}$ \\
\hline \multirow[t]{2}{*}{$5-\mathrm{HT}_{6}$} & & Ro 04-6790 & ORT & Improvement & Woolley et al. (2003) \\
\hline & & $\begin{array}{r}\text { SB-271046 } \\
\text { (oral, i.p.) }\end{array}$ & $\begin{array}{l}\text { PA, T-maze, place } \\
\text { recognition }^{\text {d }}\end{array}$ & Improvement & $\begin{array}{l}\text { Foley et al. (2004), } \\
\text { Da Silva et al. (2012) }\end{array}$ \\
\hline \multirow[t]{3}{*}{$5-\mathrm{HT}_{7}$} & AS 19 (s.c.) & & $\mathrm{P} / \mathrm{I}$ & Improvement & $\begin{array}{l}\text { Perez-Garcia and } \\
\text { Meneses (2005) }\end{array}$ \\
\hline & & SB269970 (i.p.) & DNMTP & Worsening & $\begin{array}{l}\text { Bonaventure et al. } \\
\text { (2011) }\end{array}$ \\
\hline & & $\begin{array}{l}\text { SB-269970 \& DR } \\
4004 \text { (i.p.) }\end{array}$ & $\mathrm{P} / \mathrm{I}$ & Improvement & Meneses (2004) \\
\hline $\begin{array}{l}\text { alpha7 nAChR } \\
\text { agonist/5- } \mathrm{HT}_{3} \text { antago- } \\
\text { nist }\end{array}$ & EVP-5141 (i.p.) & & PA & Improvement & Boess et al. (2013) \\
\hline
\end{tabular}

$P A$ passive avoidance, $O R T$ object recognition task, $P T$ pass through, $2 P S D$ two-platform spatial discrimination, $M W M$ Morris water maze, DMTS delayed matching to sample, DNPTP delayed non-matching to position, P/I autoshaping Pavlovian/instrumental, s.c. subcutaneous, i.p. intraperitoneal, i.v. intravenous, i.c.v. intracerebroventricular

${ }^{\text {a }}$ Combined sigma/5HT $1 \mathrm{~A}$ agonist

b Reverts the memory deficit when administered prior to, but not after, scopolamine

c In human

${ }^{\mathrm{d}}$ Partial blockade of scopolamine-induced deficit in episodic-like memory (place recognition)

De Deurwaerdere et al. 2005). Meanwhile, some studies have shown that the $5-\mathrm{HT}_{3} \mathrm{R}$ antagonists (ICS 205930 or MDL 72222) do not influence the discriminative stimulus properties of cocaine (Paris and Cunningham 1991). This suggests that $5-\mathrm{HT}_{3} \mathrm{R}$ activation plays a prominent role in the reinforcing effects of drugs of abuse. However, the 
Table 2 Interactions between serotonergic and dopaminergic pathways in memory

\begin{tabular}{|c|c|c|c|c|c|}
\hline \multirow[t]{2}{*}{ Receptors } & \multicolumn{2}{|l|}{ Ligand } & \multirow[t]{2}{*}{ Test } & \multirow{2}{*}{$\begin{array}{l}\text { Effect on cue/drug-primed } \\
\text { reinstatement of SA }\end{array}$} & \multirow[t]{2}{*}{ References } \\
\hline & Agonists & Antagonists & & & \\
\hline $5-\mathrm{HT}_{1 \mathrm{~A}}$ & & WAY 100635 (s.c.) & SA & No effect/attenuation & Burmeister et al. (2004) \\
\hline $5-\mathrm{HT}_{1 \mathrm{~B}}$ & RU24969 (i.p.) & & SA & Attenuation/attenuation & Acosta et al. (2005) \\
\hline $5-\mathrm{HT}_{2 \mathrm{~A}}$ & & M100907 (i.p.) & SA & Attenuation/no data & Nic Dhonnchadha et al. (2009) \\
\hline \multirow[t]{3}{*}{$5-\mathrm{HT}_{2 \mathrm{C}}$} & Ro60-0175 (s.c) & & SA & Attenuation/attenuation & Fletcher et al. (2008) \\
\hline & MK 212 (i.p.) & & SA & Attenuation/attenuation & Neisewander and Acosta (2007) \\
\hline & & SB242084 (i.p.) & SA & No effect/no effect & Burmeister et al. (2004) \\
\hline $5-\mathrm{HT}_{2 \mathrm{~A} / 2 \mathrm{C}}$ & & Ketanserin (i.p.) & SA & Attenuation/no effect & Burmeister et al. (2004) \\
\hline $5 \mathrm{HT}_{3}$ & & & & No data ${ }^{a}$ & Johnson et al. (2008a) \\
\hline $5-\mathrm{HT}_{6}$ & & SB-271046 and Ro-04-6790 & SA & Attenuation/no data & van Gaalen et al. (2010) \\
\hline
\end{tabular}

SA self-administration, s.c. subcutaneous, i.p. intraperitoneal

a Ondansetron did not change methamphetamine abuse, withdrawal or craving in human

potential effect of $5-\mathrm{HT}_{3} \mathrm{R}$ modulation on reinstatement and retrieval of addiction-induced memories requires further investigation. In this regard, a preliminary randomized, double-blind, placebo-controlled trial revealed that ondansetron failed to affect methamphetamine abuse, withdrawal, or craving in humans (Johnson et al. 2008a).

The $5-\mathrm{HT}_{4}$ receptor antagonists have been shown to decrease the morphine-enhanced dopaminergic firing in striatum but not in VTA (Porras et al. 2002). Moreover, pretreatment with a mixed $5-\mathrm{HT}_{3} \mathrm{R}$ and $5-\mathrm{HT}_{4} \mathrm{R}$ antagonist, DAU 6285, eliminated morphine-induced place conditioning (Bisaga et al. 1993). Although these receptors have been implicated in cocaine-induced hyperlocomotion (McMahon and Cunningham 1999), antagonists at this receptor did not influence cocaine- or amphetamine-mediated DA exocytosis (Porras et al. 2002). The role of these receptors in potentiation of addictive behaviors is yet to be elucidated.

Pretreatment with SB 258510A, the 5- $\mathrm{HT}_{6} \mathrm{R}$ antagonist, potentiates amphetamine- but not cocaine-induced hyperlocomotion and SA. Furthermore, it enhances amphetaminestimulated DA release especially in the FC (Frantz et al. 2002). The 5-HT ${ }_{6} \mathrm{R}$ agonist, ST1936, was self-administered by the rats, underlining the possible implication of this receptor in reinforcement. Furthermore, the $5-\mathrm{HT}_{6} \mathrm{R}$ antagonist, SB271046, decreased cocaine SA as well as cocainestimulated DA concentration in the NAc shell but not in the PFC (Valentini et al. 2013). Likewise, the 5- $\mathrm{HT}_{6} \mathrm{R}$ antagonists, SB-271046 and Ro04-6790, diminished cue-induced cocaine-seeking behavior, although they did not influence cocaine SA and reinforcement (van Gaalen et al. 2010). In addition, overexpression of the 5- $\mathrm{HT}_{6}$ receptors in the NAc by viral-mediated gene transfer abolished CPP to cocaine, but did not influence cocaine-induced locomotor sensitization (Ferguson et al. 2008). This suggests a potential role for $5-\mathrm{HT}_{6}$ receptors in reward learning as well as retrieval of addition-induced memory; antagonists at this receptor may help decrease relapse to the drug of abuse after extinction.

Taken together, serotonin receptors appear intriguing targets to study emotional/addiction-related learning and memory processes. Activation of 5- $\mathrm{HT}_{1 \mathrm{~B}}$ and $5-\mathrm{HT}_{2 \mathrm{C}}$ receptors as well as blockade of $5-\mathrm{HT}_{1 \mathrm{~A}}, 5-\mathrm{HT}_{2 \mathrm{~A}}, 5-\mathrm{HT}_{2 \mathrm{~A} / 2 \mathrm{C}}$ and $5-\mathrm{HT}_{6}$ receptors have been shown to decrease cue/drugprimed relapse of drug SA (Table 2).

\section{The effects of serotonin on GABAergic/glutamatergic transmission}

GABAergic interneurons in PFC contribute substantially to the inhibition of disproportionate dopaminergic activity by atypical antipsychotic drugs. This effect is proposed to be the main mechanism of cognitive enhancement by these drugs compared to the typical DA receptor blockers (Alex and Pehek 2007). Escitalopram, selective serotonin reuptake inhibitor (SSRI), reportedly boosts object recognition memory, and increases dopaminergic neuronal activity in VTA- and NMDA-induced currents in pyramidal neurons (Schilstrom et al. 2011).

Tryptophan hydroxylase-2 knockdown abolishes serotonin synthesis in the brain. Although these mice develops serotonergic neurons and projections, there have been alterations in GABAergic neurons in limbic regions of heterozygote or homozygote animals (Waider et al. 2013). Mice lacking p11, an adaptor protein of $5-\mathrm{HT}_{1 \mathrm{~B}} \mathrm{R}$, display global reduction in hippocampal GABAergic inhibition. In addition, 5- $\mathrm{HT}_{1 \mathrm{~B}} \mathrm{R}$ stimulation impairs emotional memory in the wild type, but enhances emotional memory as well as hippocampal glutamatergic transmission in adapter p11 knockout mice (Eriksson et al. 2013). Blockade of the brain $5-\mathrm{HT}_{1 \mathrm{~B}} \mathrm{R}$ by NAS-181 has also been shown to improve 
memory retention in the PA test. This facilitatory effect was reversed by muscarinic (scopolamine) or glutamatergic (MK-80) antagonists (Eriksson et al. 2008).

The 5-HT $\mathrm{HA}_{1 \mathrm{~A}}$ receptors are expressed as presynaptic heteroreceptors on pyramidal and GABAergic neurons (Santana et al. 2004, 2009) or postsynaptic in hippocampus (Carli et al. 2000). Although endogenous serotonin inhibits pyramidal firing in medial $\mathrm{PFC}$ through $5-\mathrm{HT}_{1 \mathrm{~A}}$ receptors, systemic administration of the 5- $\mathrm{HT}_{1 \mathrm{~A}}$ receptor agonists, 8-OH-DPAT, stimulates VTA projecting pyramidal neurons, which thereby results in enhanced firing of mesocortical dopaminergic receptors (Llado-Pelfort et al. 2012). This effect is thought to be mediated through GABAergic interneurons, in which $5-\mathrm{HT}_{1 \mathrm{~A}}$ receptor agonists abolishes the inhibition of GABAergic interneurons on dopaminergic transmission (Llado-Pelfort et al. 2012). Injection of the 5- $\mathrm{HT}_{1 \mathrm{~A}} \mathrm{R}$ agonist, 8-OH-DPAT, into the DRN reverses the impairment of choice accuracy due to intrahippocampal administration of 7-Cl-Kyn, an NMDA receptor antagonist (Carli et al. 2001). In addition, systemic or intrahippocampal administration of the $5-\mathrm{HT}_{1 \mathrm{~A}} \mathrm{R}$ antagonist, WAY 100635, mitigates spatial learning deficit caused by blockade of hippocampal NMDA receptors in a two-platform spatial discrimination task (Carli et al. 1999; Schiapparelli et al. 2005). Intraseptal administration of 8-OH-DPAT does not influence spatial memory (in water maze), but impairs emotional memory (in PA test); moreover, combination of intraseptal 8-OH-DPAT and subthreshold dose of the NMDA antagonist causes a profound impairment of spatial memory retention as well as mild deficit in spatial acquisition (Elvander-Tottie et al. 2009). Although the localization of $5-\mathrm{HT}_{1 \mathrm{~A}}$ receptors in relation to the glutamatergic neurons in medial septum and the adjacent vertical limb of the diagonal band of Broca area (MS/vDB) is still not characterized (Elvander-Tottie et al. 2009), in the hippocampus, 5- $\mathrm{HT}_{1 \mathrm{~A}}$ receptors are expressed on both glutamatergic pyramidal cells and inhibitory GABAergic interneurons (Aznar et al. 2003). Postsynaptic 5- $\mathrm{HT}_{1 \mathrm{~A}}$ receptors are suggested to be co-located along with NMDA receptors in the dendritic compartments (Takumi et al. 1998). NMDA infusion into the magnocellular nucleus basalis (MBN) triggers apoptotic neurodegeneration that lasts for several days and results in excitotoxic lesions (Harkany et al. 2000). Moreover, oral postlesion administration of the $5-\mathrm{HT}_{1 \mathrm{~A}} \mathrm{R}$ agonists (repinotan and 8-OH-DPAT) ameliorates NMDA excitotoxicity and improves survival of cholinergic neurons and memory performance in rats (Harkany et al. 2001). These results indicate a dual role for $5-\mathrm{HT}_{1 \mathrm{~A}}$ receptors in the modulation of Glu-induced excitatory input to hippocampus. On the one hand, activation of these receptors may hamper the NMDA-induced memory retention, thereby enhancing memory deficit caused by NMDA blockade (Elvander-Tottie et al. 2009); on the other hand, they may ameliorate NMDA-induced excitotoxicity and consequent memory deficit (Harkany et al. 2001). Taken together, the final outcome of $5-\mathrm{HT}_{1 \mathrm{~A}}$ receptor activation depends on (1) their localization in different brain areas, (2) interaction with inhibitory or excitatory neurons, (3) G-protein selectivity $\left[5-\mathrm{HT}_{1 \mathrm{~A}}\right.$ receptors are coupled to $\mathrm{G}_{\mathrm{i} 3}$ in the anterior raphe nucleus (ARN), while they mainly interact with $\mathrm{G}_{\mathrm{o}}$ proteins in the hippocampus (Mannoury la Cour et al. 2006)], and (4) agonist-directed receptor trafficking, and consequent adaptive modifications (Kenakin 1995; Li et al. 1997; Raap et al. 1999; Hensler 2002).

The activation of $5-\mathrm{HT}_{2 \mathrm{C} / 2 \mathrm{~B}}$ but not $5-\mathrm{HT}_{2 \mathrm{~A}}$ receptors produces a potent inhibitory effect on the mesolimbic and nigrostriatal dopaminergic firing (Di Giovanni et al. 1999; Di Matteo et al. 1999). This phenomenon is explained by the $5-\mathrm{HT}_{2 \mathrm{C}} \mathrm{R}$-mediated potentiation of GABAergic inhibition on dopaminergic neurons (Di Giovanni et al. 1999, 2001). Alstonine, a putative antipsychotic agent, decreases Glu uptake, which is abolished by the $5-\mathrm{HT}_{2 \mathrm{~A} / 2 \mathrm{C}}$ receptor antagonists. Glu dysfunction is also suggested to play a role in social interaction and working memory deficits (Herrmann et al. 2012). Stimulatory output from postsynaptic $5-\mathrm{HT}_{2 \mathrm{~A}}$ receptors on GABAergic interneurons enhances their inhibitory impulse, and may have potential therapeutic benefits in hippocampal and amygdala dysfunction (Bombardi and Di Giovanni 2013). In addition, M100907, a highly selective 5- $\mathrm{HT}_{2 \mathrm{~A}}$ antagonist, facilitates LTP in CA1 synapses, and potentiates NMDA responses and excitatory postsynaptic currents (EPSCs) due to electrical stimulation of CA1 hippocampal pyramidal cells (Wang and Arvanov 1998).

Using a combination of immunohistochemistry and double in situ hybridization, it has been shown that $5-\mathrm{HT}_{3 \mathrm{~A}}$ receptors are expressed on GABA neurons in the rat telencephalon. This suggests a functional interaction between these neurotransmitters (Morales et al. 2004). The 5- $\mathrm{HT}_{3} \mathrm{R}$ signaling influences both emotional and working memory. Activation of these receptors alters the expression of GABA receptor clustering protein, gephyrin, in amygdala and hippocampus after cued or contextual fear extinction, respectively, and may promotes extinction of fearful memories (Park and Williams 2012). This suggests the possible involvement of GABAergic transmission in beneficial effects of 5- $\mathrm{HT}_{3} \mathrm{R}$ on memory. In addition, 5- $\mathrm{HT}_{3}$ receptors affect working memory in the pass-through panel gates test. Intrahippocampal administration of the $5-\mathrm{HT}_{3} \mathrm{R}$ antagonist, Y-25130, recovers the working memory errors caused by cholinergic antagonism but not those due to the NMDA receptor blockade (Ohno and Watanabe 1997). Serotonergic brainstem projections to hippocampus, via $5-\mathrm{HT}_{3}$ receptors, are believed to increase the $\mathrm{GABA}_{\mathrm{B}}$-mediated inhibition in the dendritic region of pyramidal cells. In this regard, the $5-\mathrm{HT}_{3}$ antagonist, ondansetron, facilitates theta 
frequency and significantly augments the magnitude and duration of LTP due to electrical stimulation in freely moving rats (Staubli and Xu 1995).

Modulation of the 5- $\mathrm{HT}_{6}$ receptor activity has shown promise in the treatment for cognitive disorders. The $5-\mathrm{HT}_{6}$ $\mathrm{R}$ antagonist SB-271046 increases extracellular Glu levels in both FC and DH, but not in striatum or NAc (Dawson et al. 2001). The enhancement of excitatory neurotransmission is involved in the augmented Ach release by $5-\mathrm{HT}_{6} \mathrm{R}$ antagonists (Marcos et al. 2006). The 5- $\mathrm{HT}_{6} \mathrm{R}$ antagonist, Ro 04-6790, enhances memory consolidation, and prevents delay-induced extinction of object discrimination (King et al. 2004). Moreover, post-training administration of Ro 04-6790 recovers recognition deficit, hypermotility and ataxia produced by MK-801, an NMDA antagonist (Pitsikas et al. 2008). Similarly, pretreatment with NMDA antagonists prevents the beneficial effects of $5-\mathrm{HT}_{6} \mathrm{R}$ blockade on memory (King et al. 2004). In this regard, the favorable effects of $5-\mathrm{HT}_{6}$ receptor antagonism on memory and schizophrenia are reviewed elsewhere (Mitchell and Neumaier 2005; Johnson et al. 2008b; Marsden et al. 2011). The serotonin- 6 receptors are co-localized with glutamic acid decarboxylase (GAD) in GABAergic neurons within multiple brain regions (Woolley et al. 2004), suggesting that increased Glu concentration due to $5-\mathrm{HT}_{6}$ blockade can be indirectly mediated through GABAergic system (Dawson et al. 2001; West et al. 2009). The 5-HT 6 receptor agonist, E-6801, is also demonstrated to enhance object recognition memory mainly through cholinergic and glutamatergic pathways (Kendall et al. 2011). In this regard, combination of sub-effective doses of E-6801 $(1 \mathrm{mg} / \mathrm{kg})$ with donepezil (indirect cholinergic agonist) or memantine (NMDA antagonist) significantly enhances object recognition memory. Moreover, the efficacy of E-6801 in reversing scopolamine $(0.5 \mathrm{mg} / \mathrm{kg})$-induced impairment is comparable to that of donepezil $(0.3$ and $1 \mathrm{mg} / \mathrm{kg}$ ) (Kendall et al. 2011). In addition, both blockade and activation of 5- $\mathrm{HT}_{6}$ receptors reverse scopolamine or MK-801-induced memory deficit in cue-linked emotional fear response (Woods et al. 2012). It should be noted that the $5-\mathrm{HT}_{6} \mathrm{R}$ agonists, WAY-181187, attenuates LTP, and enhances spontaneous inhibitory postsynaptic current (sIPSC) in brain slices containing CA1 of the hippocampus through an increase in extracellular GABA concentration (West et al. 2009).

The 5- $\mathrm{HT}_{7}$ receptor antagonist, SB269970, alleviates object recognition impairment due to the NMDA antagonists, phencyclidine (Horiguchi et al. 2011b) and MK-801 (Bonaventure et al. 2011), but aggravates the deficit caused by anticholinergic agents (Bonaventure et al. 2011). Electrophysiological studies on hippocampal slices, however, revealed that $5-\mathrm{HT}_{7} \mathrm{R}$ activation reverses metabotropic Glu receptor-induced long-term depression (LTD) (Costa et al. 2012).
Activation of the metabotropic Glu $2 / 3$ receptor $\left(\mathrm{mGlu}_{2 / 3} \mathrm{R}\right)$ enhances clozapine alleviation of phencyclidine-induced impairment in object recognition. Moreover, positive effects of clozapine are also reversed by LY341495, an $\mathrm{mGlu}_{2 / 3} \mathrm{R}$ antagonist, suggesting a possible crosstalk between serotonin and metabotropic Glu receptors (Horiguchi et al. 2011a).

In summary, blockade of $5-\mathrm{HT}_{1 \mathrm{~B}}$ and $5-\mathrm{HT}_{7}$ receptors improves memory deficit caused by glutamatergic blockade or lesions. In this regard, the effect of $5-\mathrm{HT}_{1 \mathrm{~A}}$ and $5-\mathrm{HT}_{6}$ receptors depends on the activity of specific receptors in different brain areas, where both agonists and antagonists have been shown to produce beneficial effects (Table 3).

\section{The effects of serotonin on amyloidogenesis}

The APP is a type I integral membrane glycoprotein in mammalian cells. Cleavage of APP at the $\mathrm{N}$-terminus of amyloid $\beta$ peptide $(\mathrm{A} \beta)$ by $\beta$-secretase or at the $\mathrm{C}$-terminus by $\gamma$-secretase results in amyloidogenesis and aggregation of $A \beta$ in the brain. In contrast, $\alpha$-secretase activity yields a large soluble $\mathrm{N}$-terminal ectodomain named SAPP $\alpha$ into the extracellular space, which offers neuroprotective and memory-enhancing properties (Postina 2012). Degeneration of the serotonergic neurons is suggested to be involved in $A \beta$ induced cognitive damage in dogs (Bernedo et al. 2009). In addition, high tryptophan diet $(0.40 \mathrm{~g} / 100 \mathrm{~g}$ for 1 month $)$ reduced intraneuronal $A \beta$ deposits in triple transgenic mouse model of AD ( $3 \times \mathrm{TT}-\mathrm{AD})$. This suggests a potential benefit for elevated 5-HT content in the reduction in amyloidogenesis in AD (Noristani et al. 2012). Moreover, A $\beta$ injection is proposed to cause a transient overexpression of $5-\mathrm{HT}_{1 \mathrm{~A}}$ receptors in astroglial cells in response to the local neuronal loss (Verdurand et al. 2011).

Paroxetine, an SSRI, is shown to decrease APP expression (Payton et al. 2003). Moreover, direct infusion of serotonin into the hippocampus as well as treatment with several SSRIs decreases the levels of $A \beta$ in brain interstitial fluid in presenilin-1 (PS1)/APP double-transgenic mice model of AD (Cirrito et al. 2011). Similarly, imipramine and citalopram enhance the secreted APP from primary rat basal forebrain neurons (Pakaski et al. 2005). In addition, a retrospective positron emission tomography (PET) analysis has revealed lower load of amyloid in patients treated with anti-depressants (Cirrito et al. 2011); thereby, a variety of these agents have been evaluated for cognitive-enhancing properties in AD (Rodriguez et al. 2012).

Stimulation of 5-HT $2 \mathrm{a} / 2 \mathrm{c}$ receptors in cultured $3 \mathrm{~T} 3$ cells accelerates the secretion of the soluble APP mainly through phospholipase A2 (PLA2) or protein kinase C (PKC) (Nitsch et al. 1996). Moreover, dexnorfenfluramine, the $5-\mathrm{HT}_{2 \mathrm{C}} \mathrm{R}$ agonist, as well as meta-chlorophenylpiperazine 
Table 3 Interactions between serotonergic and glutamatergic transmission in memory

\begin{tabular}{|c|c|c|c|c|c|}
\hline \multirow[t]{2}{*}{ Receptors } & \multicolumn{2}{|l|}{ Ligand } & \multirow[t]{2}{*}{ Test } & \multirow{2}{*}{$\begin{array}{l}\text { Effect on memory deficit } \\
\text { due to glutamatergic } \\
\text { blockade or lesions }\end{array}$} & \multirow[t]{2}{*}{ References } \\
\hline & Agonists & Antagonists & & & \\
\hline \multirow[t]{3}{*}{$5 \mathrm{HT}_{1 \mathrm{~A}}$} & $\begin{array}{l}\text { 8-OH-DPAT (dorsal } \\
\text { raphe) }\end{array}$ & & 2PSD & Improvement & Carli et al. (2001) \\
\hline & $\begin{array}{l}\text { Repinotan and 8-OH- } \\
\text { DPAT (oral) }\end{array}$ & & PA, neural survival & Improvement & Harkany et al. (2001) \\
\hline & & $\begin{array}{l}\text { WAY } 100635 \text { (S.C., } \\
\text { intrahippocampal) }\end{array}$ & 2PSD & Improvement & Carli et al. (1999) \\
\hline $5-\mathrm{HT}_{1 \mathrm{~B}}$ & & NAS-181 (s.c.) & PA & Improvement & Eriksson et al. (2008) \\
\hline $5-\mathrm{HT}_{3}$ & & $\begin{array}{l}\text { Y-25130 (intra } \\
\text { hippocampal) }\end{array}$ & PT & No effect & Ohno and Watanabe (1997) \\
\hline \multirow[t]{2}{*}{$5-\mathrm{HT}_{6}$} & $\begin{array}{l}\text { E-6801 (i.p), EMD } \\
386088 \text { (i.p.) }\end{array}$ & & CER & Improvement & Woods et al. (2012) \\
\hline & & SB-270146 (i.p.) & CER & Improvement & Woods et al. (2012) \\
\hline $5-\mathrm{HT}_{7}$ & & SB269970 (i.p.) & ORT, DNMTP & Improvement & $\begin{array}{l}\text { Bonaventure et al. (2011), } \\
\text { Horiguchi et al. (2011a, b) }\end{array}$ \\
\hline
\end{tabular}

$P A$ passive avoidance, $O R T$ object recognition task, $P T$ pass through, $2 P S D$ two-platform spatial discrimination, DNPTP delayed non-matching to position, $C E R$ conditioned emotional response

(mCPP), the $5-\mathrm{HT}_{2 \mathrm{~b} / 2 \mathrm{c}} \mathrm{R}$ agonist, increases the soluble APP concentration in cerebrospinal fluid of guinea pigs (Arjona et al. 2002). As the production of soluble APP precludes the formation of amyloidogenic derivatives, agonists at this receptor are potential targets for the treatment of AD.

The 5- $\mathrm{HT}_{3}$ receptors are ligand-gated ion channels, which cause neural depolarization and excitation (Maricq et al. 1991). Blockade of these receptors is shown to protect against ischemia-induced injury in hippocampal slices (Kagami et al. 1992) or A $\beta$ (25-35)-induced neurotoxicity in cultured cortical neurons ( $\mathrm{Ju}$ Yeon and Yeon Hee 2005). These effects are contributed to the inhibition of $A \beta$-mediated increase in levels of calcium, Glu, TNF$\alpha$, NF-кB, iNOS, COX-2, active caspase 3 , cytochrome c and calcineurin phosphatase (Ju Yeon and Yeon Hee 2005; Rahimian et al. 2013). This suggests $5-\mathrm{HT}_{3}$ blockers as potential therapeutic agents for the inhibition of amyloidinduced neurotoxicity (Fakhfouri et al. 2012).

Activation of the 5- $\mathrm{HT}_{4}$ receptors switches the APP metabolism to the non-amyloidogenic pathway resulting in the production of SAPP $\alpha$ in cultured CHO cells (Robert et al. 2001). Moreover, this effect was demonstrated to be due to specific alterations in $\alpha$-secretase activity. The pathways downstream of this process has been reported to include the cAMP-regulated guanine nucleotide exchange factor, exchange proteins activated by cAMP (EPAC) and the small GTPase, Rac (Fig. 1) (Robert et al. 2005). Similarly, the 5- $\mathrm{HT}_{4} \mathrm{R}$ partial agonist, RS67333, increases survival and prevents the production of $A \beta$ peptide in primary cortical cultures of transgenic mice expressing human APP (Cho and $\mathrm{Hu}$ 2007). The possible correlation of serotonin

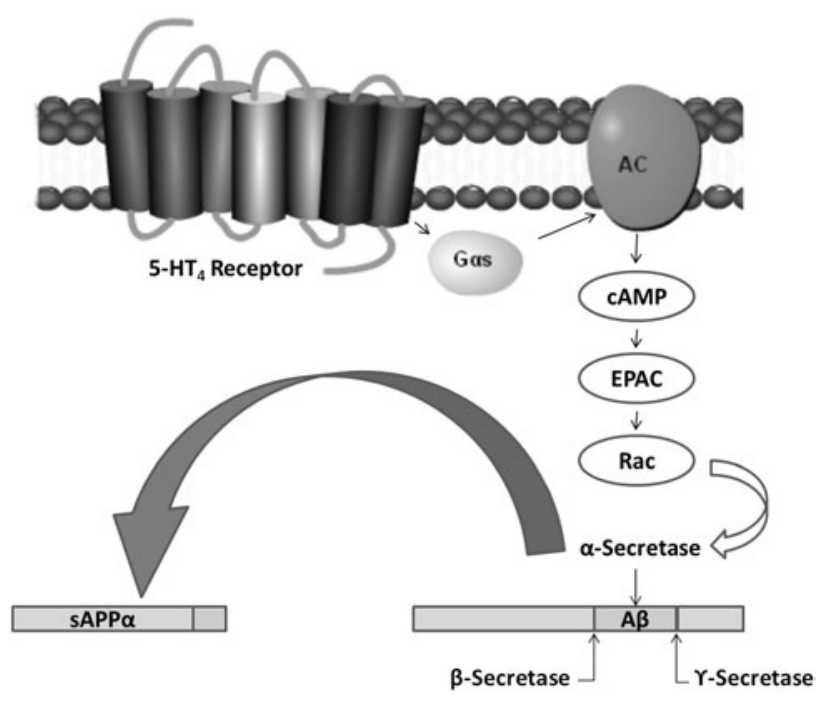

Fig. 1 The effects of 5- $\mathrm{HT}_{4}$ receptor activation on amyloidogenesis. Activation of the 5-HT4 receptors alters $\alpha$-secretase activity and switches the metabolism of amyloid precursor protein (APP) toward the generation of soluble form of APP $(\operatorname{sAPP} \alpha)$. The pathways downstream to the receptor have been reported to include the cAMPregulated guanine nucleotide exchange factor, Epac and the small GTPase, Rac (Robert et al. 2001, 2005; Lezoualc'h 2007). AC, adenylate cyclase; $\mathrm{G} \alpha$ s, Stimulatory G-protein; EPAC, exchange proteins activated by cAMP; $\mathrm{A} \beta$, amyloid beta

transmission with amyloid plaque formation was also investigated in $\mathrm{AD}$ patients using PET. No significant change was observed in cerebral $5-\mathrm{HT}_{4}$ receptor density in $\mathrm{AD}$ patients based on the clinical criteria. In contrast, patients with positive $A \beta$ burden displayed upregulation of 
cerebral 5- $\mathrm{HT}_{4}$ receptors (Madsen et al. 2011). This finding points to the upregulation of $5-\mathrm{HT}_{4}$ receptor as a potential diagnostic marker in early stages of the disease. Additionally, agonists at this receptor may help reduce the formation of amyloid deposits (Lezoualc'h 2007).

The 5- $\mathrm{HT}_{6}$ receptors are also positively coupled to adenylate cyclase (AC) activation; therefore, a similar effect to that of 5- $\mathrm{HT}_{4}$ receptors (formation of non-amyloidogenic derivatives) is conceivable for this subtype, though yet to be elucidated (Postina 2012). Meanwhile, antagonists at this receptor improve cognitive function in a number of hippocampal-dependent tasks (see previous sections) and are undergoing clinical trials as novel cognitive-enhancing agents for $\mathrm{AD}$ (Upton et al. 2008).

Taken together, 5- $\mathrm{HT}_{2}$ and $5-\mathrm{HT}_{4}$ receptors agonists as well as $5-\mathrm{HT}_{3}$ blockers appear promising therapeutic approaches to reduce the progression of neurodegeneration in Alzheimer's disease.

\section{The effects of serotonin on intracellular pathways}

Multiple intracellular pathways are involved in neural plasticity, memory formation and sensitization by 5-HT. A large body of evidence in vertebrates and/or invertebrates indicates that serotonin influences memory through second messengers and effectors including cyclic adenosine monophosphate (cAMP) (Bevilaqua et al. 1997; Perez-Garcia and Meneses 2008a; Lee et al. 2009; McLean et al. 2009), cyclic guanosine monophosphate (cGMP) (van Donkelaar et al. 2008), PKC (Byrne and Kandel 1996; Barbas et al. 2003), mitogen-activated protein kinases (MAPK) (Cammarota et al. 2008; Carlini et al. 2012) and glycogen synthase kinase 3 (GSK3) (Polter and Li 2010).

Serotonin prolongs action potentials and increases neural excitability, spike duration and synaptic strength in a cAMP-dependent manner in marine Aplysia (Goldsmith and Abrams 1992). In addition, overexpression of Aplysia 5-HTapAC1 in mammalian HEK293 cells and in Xenopus oocytes increases cAMP content of the cell. Likewise, 5-HTapAC1 dsRNA hinders 5-HT-induced cAMP production, membrane excitability, spike duration and synaptic facilitation in non-depressed or partially depressed synapses (Lee et al. 2009). The 5- $\mathrm{HT}_{1 \mathrm{~A}}$ receptor (negatively coupled to AC) agonist, tandospirone, has been shown to inhibit hippocampal LTP in vivo (Mori et al. 2001), whereas $5-\mathrm{HT}_{4} \mathrm{R}$ (positively coupled to $\mathrm{AC}$ ) agonists are shown to facilitate LTP (Matsumoto et al. 2001). In contrast, the activation of the $5-\mathrm{HT}_{6}$ receptors, though positively couple to $\mathrm{AC}$, attenuates LTP in hippocampus mainly through an increase in GABAergic transmission (West et al. 2009).
Serotonin modulation of cyclic nucleosides is also involved in memory formation and consolidation. Acute tryptophan depletion impairs ORT performance in rats (Rutten et al. 2007a). The phosphodiesterase 4 (PDE4) inhibitor, rolipram, increases cAMP level and subsequently restores memory impairment due to tryptophan depletion (Yuan et al. 2000; Rutten et al. 2007a). A role for cAMP/protein kinase A (PKA)/cAMP-response element-binding protein (CREB) in the hippocampus is also suggested for memory consolidation downstream of $5-\mathrm{HT}_{1 \mathrm{~A}}$ receptors in rats using passive avoidance test (Bevilaqua et al. 1997). In this regard, post-training intrahippocampal injection of NAN-190, the $5-\mathrm{HT}_{1 \mathrm{~A}} \mathrm{R}$ antagonist, increases memory retention in one-trial stepdown test, whereas 8-OH-DPAT, the $5-\mathrm{HT}_{1 \mathrm{~A}} \mathrm{R}$ agonist, causes retrograde amnesia (Bevilaqua et al. 1997). Activation of $5-\mathrm{HT}_{4}$ receptors by RS 67333 enhances information acquisition in object recognition test. Moreover, stimulation of 5- $\mathrm{HT}_{4}$ receptors results in the activation of particulate PDE in the PFC and the hippocampus (Levallet et al. 2009). The 5- $\mathrm{HT}_{4} \mathrm{R}$ partial agonist, SL65.0155, reportedly increased cAMP production and improved learning and memory. Furthermore, it improved scopolamine- or age-induced cognitive deficits in the MWM, and showed synergistic therapeutic effects when combined with rivastigmine (a cholinesterase inhibitor) (Moser et al. 2002). The $5-\mathrm{HT}_{1 \mathrm{~A} / 7} \mathrm{R}$ agonist, 8-OH-DPAT as well as the $5-\mathrm{HT}_{7} \mathrm{R}$ agonist, AS19, facilitated memory formation and consolidation in PI autoshaping test. The raphe nuclei and PFC have shown higher cAMP contents in trained animals treated with AS19, but there has been a reduction in cAMP levels in the raphe nuclei of those treated with 8-OH-DPAT. These results are attributed to positive $\left(5-\mathrm{HT}_{7} \mathrm{R}\right)$ or negative $\left(5-\mathrm{HT}_{1 \mathrm{~A}} \mathrm{R}\right)$ coupling to AC (PerezGarcia and Meneses 2008a). Another study reported an increased cAMP production in cortical and hippocampal areas following the administration of 8-OH-DPAT (Manuel-Apolinar and Meneses 2004). This discrepancy could emerge from different time courses in training and testing sessions (Perez-Garcia and Meneses 2008a). Acute administration of MDMA in rats augmented LTP in CA3-CA1 synapses through presynaptic 5- $\mathrm{HT}_{2}$ receptors and postsynaptic DA $\left(\mathrm{D}_{1} / \mathrm{D}_{5}\right)$ receptors (Rozas et al. 2012). This effect was abolished by PKA inhibitors, suggesting the involvement of cAMP-dependent mechanisms (Rozas et al. 2012). Serotonin depletion of olfactory bulb impaired conditioned odor preference, which was further restored by 5- $\mathrm{HT}_{2 \mathrm{~A} / 2 \mathrm{C}}$ agonists (Price et al. 1998; Yuan et al. 2003) or when cAMP levels were increased by adrenergic stimulation (Yuan et al. 2000) or cilomilast, PDE inhibitor, in the neonate rats (McLean et al. 2009).

Long-term potentiation by serotonin in Aplysia involves the activation of PKC (Sacktor et al. 1988), protein kinase 
M (PKM) (Cai et al. 2011), phosphoinositide 3-kinase (PI3K) (Hu et al. 2011), MAPK (Martin et al. 1997) and synapsin (Angers et al. 2002; Hart et al. 2011). Long-term facilitation in invertebrates and vertebrates involves gene expression downstream to CREB. Moreover, serotoninfacilitated synaptic transmission can be explained by the subsequent activation of PKC, which itself causes ubiquitination and degradation of CREB repressor (Upadhya et al. 2004). PKC is also the main mediator of serotoninaugmented membrane excitability at depressed synapses (Sacktor et al. 1988; Byrne and Kandel 1996). The possible involvement of these signaling pathways in other species requires further investigation (Cammarota et al. 2008). In this regard, serotonin caused an early depression (lasting for 30-50 min, via $5-\mathrm{HT}_{1 \mathrm{~A}}$ receptors) or a late, long-lasting facilitation (lasting for more than $5 \mathrm{~h}$, via $5-\mathrm{HT}_{4}$ receptors) in amygdala slice recordings. The later effect was blocked by the inhibitors of PKA and extracellular signal-regulated kinase (ERK), suggesting the possible involvement of these pathways in serotonin-mediated facilitation (Huang and Kandel 2007). Moreover, disinhibition of $5-\mathrm{HT}_{1 \mathrm{~A}} \mathrm{R} / \mathrm{MEK} / \mathrm{Arc}$ or stimulation of $5-\mathrm{HT}_{4} \mathrm{R} /$ $\mathrm{MEK} /$ Arc signaling cascades improved emotional memory in PA test in genetic models of depression (Eriksson et al. 2012).

Although cGMP/protein kinase G (PKG)/nitric oxide (NO) pathway is involved in memory formation and consolidation (Blokland et al. 2006; Rutten et al. 2007b), the possible involvement of these pathways in serotonin-mediated alteration in cognitive functions is yet to be elucidated. In this regard, it is reported that PDE-5 inhibition, which reduce cGMP degradation, mitigates the impairment of objective memory due to acute tryptophan depletion in male Wistar rats (van Donkelaar et al. 2008).

\section{Conclusion}

The effects of serotonin on memory depend on the activation of pre/post-synaptic serotonergic receptors located on distinct subsets of neurons. To add to the complexity, in different experimental settings, activation of these receptors leads to the effects, which are not always consistent. Many of these effects are produced through the modification of cholinergic, dopaminergic, GABAergic or glutamatergic transmission. As discussed here, the activation state of serotonin receptors can affect memory deficits due to muscarinic/glutamatergic blockade or lesions. Moreover, serotonin receptor ligands influence emotional/fearful learning and memory. Interestingly, $5-\mathrm{HT}_{3} \mathrm{R}$ antagonists as well as $5-\mathrm{HT}_{4} \mathrm{R}$ agonists have been demonstrated to decrease amyloidogenesis and appear promising in the treatment for Alzheimer's disease.

\section{References}

Acosta JI, Boynton FA, Kirschner KF, Neisewander JL (2005) Stimulation of 5-HT1B receptors decreases cocaine- and sucroseseeking behavior. Pharmacol Biochem Behav 80:297-307. doi:10.1016/j.pbb.2004.12.001

Alex KD, Pehek EA (2007) Pharmacologic mechanisms of serotonergic regulation of dopamine neurotransmission. Pharmacol Ther 113:296-320. doi:10.1016/j.pharmthera.2006.08.004

Altman HJ, Stone WS, Ogren SO (1987) Evidence for a possible functional interaction between serotonergic and cholinergic mechanisms in memory retrieval. Behav Neural Biol 48:49-62

Andrews CM, Kung HF, Lucki I (2005) The 5-HT1A receptor modulates the effects of cocaine on extracellular serotonin and dopamine levels in the nucleus accumbens. Eur J Pharmacol 508:123-130. doi:10.1016/j.ejphar.2004.12.033

Angers A, Fioravante D, Chin J, Cleary LJ, Bean AJ (2002) Byrne JH (2002) Serotonin stimulates phosphorylation of Aplysia synapsin and alters its subcellular distribution in sensory neurons. $\mathrm{J}$ Neurosci 22:5412-5422.

Arjona AA, Pooler AM, Lee RK, Wurtman RJ (2002) Effect of a 5-HT(2C) serotonin agonist, dexnorfenfluramine, on amyloid precursor protein metabolism in guinea pigs. Brain Res 951:135-140

Aznar S, Qian Z, Shah R, Rahbek B, Knudsen GM (2003) The 5-HT1A serotonin receptor is located on calbindin- and parvalbumin-containing neurons in the rat brain. Brain Res 959:58-67

Barbas D, DesGroseillers L, Castellucci VF, Carew TJ, Marinesco S (2003) Multiple serotonergic mechanisms contributing to sensitization in Aplysia: evidence of diverse serotonin receptor subtypes. Learn Mem 10:373-386. doi:10.1101/lm.66103

Barnes NM, Sharp T (1999) A review of central 5-HT receptors and their function. Neuropharmacology 38:1083-1152

Bernedo V, Insua D, Suarez ML, Santamarina G, Sarasa M, Pesini $P$ (2009) Beta-amyloid cortical deposits are accompanied by the loss of serotonergic neurons in the dog. J Comp Neurol 513:417-429. doi:10.1002/cne.21985

Bevilaqua L, Ardenghi P, Schroder N et al (1997) Drugs acting upon the cyclic adenosine monophosphate/protein kinase A signalling pathway modulate memory consolidation when given late after training into rat hippocampus but not amygdala. Behav Pharmacol 8:331-338

Bisaga A, Sikora J, Kostowski W (1993) The effect of drugs interacting with serotonergic 5HT3 and 5HT4 receptors on morphine place conditioning. Pol J Pharmacol 45:513-519

Blokland A, Schreiber R, Prickaerts J (2006) Improving memory: a role for phosphodiesterases. Curr Pharm Des 12:2511-2523

Boess FG, de Vry J, Erb C et al (2013) Pharmacological and behavioral profile of $\mathrm{N}-[(3 \mathrm{R})-1$-azabicyclo[2.2.2]oct-3-yl]6-chinolincarboxamide (EVP-5141), a novel alpha7 nicotinic acetylcholine receptor agonist/serotonin 5-HT3 receptor antagonist. Psychopharmacology 227:1-17. doi:10.1007/ s00213-012-2933-4

Bombardi C, Di Giovanni G (2013) Functional anatomy of 5-HT2A receptors in the amygdala and hippocampal complex: relevance to memory functions. Exp Brain Res 230:427-439. doi:10.1007/s00221-013-3512-6

Bonaventure P, Aluisio L, Shoblock J et al (2011) Pharmacological blockade of serotonin 5-HT(7) receptor reverses working memory deficits in rats by normalizing cortical glutamate neurotransmission. PLoS One 6:e20210. doi:10.1371/ journal.pone.0020210

Boulougouris V, Tsaltas E (2008) Serotonergic and dopaminergic modulation of attentional processes. Prog Brain Res 172:517542. doi:10.1016/S0079-6123(08)00925-4 
Brambilla A, Ghiorzi A, Pitsikas N, Borsini F (1993) DAU 6215, a novel 5-HT3-receptor antagonist, selectively antagonizes scopolamine-induced deficit in a passive-avoidance task, but not scopolamine-induced hypermotility in rats. J Pharm Pharmacol 45:841-843

Broocks A, Little JT, Martin A et al (1998) The influence of ondansetron and $\mathrm{m}$-chlorophenylpiperazine on scopolamine-induced cognitive, behavioral, and physiological responses in young healthy controls. Biol Psychiatry 43:408-416

Burmeister JJ, Lungren EM, Kirschner KF, Neisewander JL (2004) Differential roles of 5-HT receptor subtypes in cue and cocaine reinstatement of cocaine-seeking behavior in rats. Neuropsychopharmacology 29:660-668. doi:10.1038/sj.npp.1300346

Byrne JH, Kandel ER (1996) Presynaptic facilitation revisited: state and time dependence. J Neurosci 16:425-435

Cai D, Pearce K, Chen S, Glanzman DL (2011) Protein kinase M maintains long-term sensitization and long-term facilitation in Aplysia. J Neurosci 31:6421-6431. doi:10.1523/JNEURO SCI.4744-10.2011

Cammarota M, Bevilaqua LR, Medina JH, Izquierdo I (2008) ERK1/2 and CaMKII-mediated events in memory formation: is 5HT regulation involved? Behav Brain Res 195:120-128. doi:10.1016/j.bbr.2007.11.029

Campbell AD, McBride WJ (1995) Serotonin-3 receptor and ethanolstimulated dopamine release in the nucleus accumbens. Pharmacol Biochem Behav 51:835-842

Carboni E, Acquas E, Leone P, Di Chiara G (1989) 5HT3 receptor antagonists block morphine- and nicotine- but not amphetamine-induced reward. Psychopharmacology 97:175-178

Carey RJ, Depalma G, Damianopoulos E, Muller CP, Huston JP (2004) The 5-HT1A receptor and behavioral stimulation in the rat: effects of 8-OHDPAT on spontaneous and cocaine-induced behavior. Psychopharmacology 177:46-54. doi:10.1007/ s00213-004-1917-4

Carli M, Bonalumi P, Samanin R (1997a) WAY 100635, a 5-HT1A receptor antagonist, prevents the impairment of spatial learning caused by intrahippocampal administration of scopolamine or 7-chloro-kynurenic acid. Brain Res 774:167-174

Carli M, Luschi R, Samanin R (1997b) Dose-related impairment of spatial learning by intrahippocampal scopolamine: antagonism by ondansetron, a 5-HT3 receptor antagonist. Behav Brain Res $82: 185-194$

Carli M, Bonalumi P, Samanin R (1998) Stimulation of 5-HT1A receptors in the dorsal raphe reverses the impairment of spatial learning caused by intrahippocampal scopolamine in rats. Eur $\mathrm{J}$ Neurosci 10:221-230

Carli M, Silva S, Balducci C, Samanin R (1999) WAY 100635, a 5-HT1A receptor antagonist, prevents the impairment of spatial learning caused by blockade of hippocampal NMDA receptors. Neuropharmacology 38:1165-1173

Carli M, Balducci C, Samanin R (2000) Low doses of 8-OH-DPAT prevent the impairment of spatial learning caused by intrahippocampal scopolamine through $5-\mathrm{HT}(1 \mathrm{~A})$ receptors in the dorsal raphe. Br J Pharmacol 131:375-381. doi:10.1038/sj. bjp. 0703567

Carli M, Balducci C, Samanin R (2001) Stimulation of 5-HT(1A) receptors in the dorsal raphe ameliorates the impairment of spatial learning caused by intrahippocampal 7-chloro-kynurenic acid in naive and pretrained rats. Psychopharmacology 158:3947. doi: $10.1007 / \mathrm{s} 002130100837$

Carlini VP, Poretti MB, Rask-Andersen M et al (2012) Differential effects of fluoxetine and venlafaxine on memory recognition: possible mechanisms of action. Prog Neuropsychopharmacol Biol Psychiatry 38:159-167. doi:10.1016/j.pnpbp.2012.03.004

Cervo L, Rozio M, Ekalle-Soppo CB, Carnovali F, Santangelo E, Samanin R (2002) Stimulation of serotonin1B receptors induces conditioned place aversion and facilitates cocaine place conditioning in rats. Psychopharmacology 163:142-150. doi: 10.1007/s00213-002-1145-8

Chen J, Paredes W, Van Praag HM, Lowinson JH, Gardner EL (1992) Presynaptic dopamine release is enhanced by 5-HT3 receptor activation in medial prefrontal cortex of freely moving rats. Synapse 10:264-266. doi:10.1002/syn.890100308

Cho S, Hu Y (2007) Activation of 5-HT4 receptors inhibits secretion of beta-amyloid peptides and increases neuronal survival. Exp Neurol 203:274-278. doi:10.1016/j.expneurol.2006.07.021

Chugh Y, Saha N, Sankaranarayanan A, Datta H (1991) Enhancement of memory retrieval and attenuation of scopolamine-induced amnesia following administration of 5-HT3 antagonist ICS 205930. Pharmacol Toxicol 69:105-106

Cirrito JR, Disabato BM, Restivo JL et al (2011) Serotonin signaling is associated with lower amyloid-beta levels and plaques in transgenic mice and humans. Proc Natl Acad Sci U S A 108:14968-14973. doi:10.1073/pnas.1107411108

Consolo S, Arnaboldi S, Giorgi S, Russi G, Ladinsky H (1994) 5-HT4 receptor stimulation facilitates acetylcholine release in rat frontal cortex. Neuroreport 5:1230-1232

Costa L, Spatuzza M, D'Antoni S et al (2012) Activation of 5-HT7 serotonin receptors reverses metabotropic glutamate receptormediated synaptic plasticity in wild-type and Fmr1 knockout mice, a model of Fragile X syndrome. Biol Psychiatry 72:924933. doi:10.1016/j.biopsych.2012.06.008

Da Silva Costa-Aze V, Quiedeville A, Boulouard M, Dauphin F (2012) 5-HT6 receptor blockade differentially affects scopolamine-induced deficits of working memory, recognition memory and aversive learning in mice. Psychopharmacology 222:99115. doi:10.1007/s00213-011-2627-3

Dawson LA, Nguyen HQ, Li P (2001) The 5-HT(6) receptor antagonist SB-271046 selectively enhances excitatory neurotransmission in the rat frontal cortex and hippocampus. Neuropsychopharmacology 25:662-668. doi:10.1016/ S0893-133X(01)00265-2

De Deurwaerdere P, Moison D, Navailles S, Porras G, Spampinato U (2005) Regionally and functionally distinct serotonin3 receptors control in vivo dopamine outflow in the rat nucleus accumbens. J Neurochem 94:140-149. doi:10.1111/j.1471-4159.2005.03174.x

Di Giovanni G, De Deurwaerdere P, Di Mascio M, Di Matteo V, Esposito E, Spampinato U (1999) Selective blockade of serotonin-2C/2B receptors enhances mesolimbic and mesostriatal dopaminergic function: a combined in vivo electrophysiological and microdialysis study. Neuroscience 91:587-597

Di Giovanni G, Di Matteo V, La Grutta V, Esposito E (2001) m-Chlorophenylpiperazine excites non-dopaminergic neurons in the rat substantia nigra and ventral tegmental area by activating serotonin-2C receptors. Neuroscience 103:111-116

Di Matteo V, Di Giovanni G, Di Mascio M, Esposito E (1999) SB 242084 , a selective serotonin2C receptor antagonist, increases dopaminergic transmission in the mesolimbic system. Neuropharmacology 38:1195-1205

Diaz-Mataix L, Scorza MC, Bortolozzi A, Toth M, Celada P, Artigas F (2005) Involvement of 5-HT1A receptors in prefrontal cortex in the modulation of dopaminergic activity: role in atypical antipsychotic action. J Neurosci 25:10831-10843. doi:10.1523/ JNEUROSCI.2999-05.2005

Elvander-Tottie E, Eriksson TM, Sandin J, Ogren SO (2009) 5-HT(1A) and NMDA receptors interact in the rat medial septum and modulate hippocampal-dependent spatial learning. Hippocampus 19:1187-1198. doi:10.1002/hipo.20596

Eriksson TM, Madjid N, Elvander-Tottie E, Stiedl O, Svenningsson P, Ogren SO (2008) Blockade of 5-HT 1B receptors facilitates contextual aversive learning in mice by 
disinhibition of cholinergic and glutamatergic neurotransmission. Neuropharmacology 54:1041-1050. doi:10.1016/j.neurop harm.2008.02.007

Eriksson TM, Delagrange P, Spedding M, Popoli M, Mathe AA, Ogren SO, Svenningsson P (2012) Emotional memory impairments in a genetic rat model of depression: involvement of 5-HT/MEK/Arc signaling in restoration. Mol Psychiatry 17:173-184. doi:10.1038/mp.2010.131

Eriksson TM, Alvarsson A, Stan TL et al (2013) Bidirectional regulation of emotional memory by 5-HT1B receptors involves hippocampal p11. Mol Psychiatry 18:1096-1105. doi:10.1038 /mp.2012.130

Fakhfouri G, Rahimian R, Ghia JE, Khan WI, Dehpour AR (2012) Impact of 5-HT(3) receptor antagonists on peripheral and central diseases. Drug Discov Today 17:741-747. doi:10.1016/j.drudis.2012.02.009

Ferguson SM, Mitchell ES, Neumaier JF (2008) Increased expression of 5-HT6 receptors in the nucleus accumbens blocks the rewarding but not psychomotor activating properties of cocaine. Biol Psychiatry 63:207-213. doi:10.1016/j.biopsych.2007.02.018

Filip M, Cunningham KA (2003) Hyperlocomotive and discriminative stimulus effects of cocaine are under the control of serotonin(2C) (5-HT(2C)) receptors in rat prefrontal cortex. J Pharmacol Exp Ther 306:734-743. doi:10.1124/j pet.102.045716

Fletcher PJ, Chintoh AF, Sinyard J, Higgins GA (2004) Injection of the 5-HT2C receptor agonist Ro60-0175 into the ventral tegmental area reduces cocaine-induced locomotor activity and cocaine self-administration. Neuropsychopharmacology 29:308-318. doi:10.1038/sj.npp.1300319

Fletcher PJ, Rizos Z, Sinyard J, Tampakeras M, Higgins GA (2008) The 5-HT2C receptor agonist Ro60-0175 reduces cocaine self-administration and reinstatement induced by the stressor yohimbine, and contextual cues. Neuropsychopharmacology 33:1402-1412. doi:10.1038/sj.npp.1301509

Foley AG, Murphy KJ, Hirst WD et al (2004) The 5-HT(6) receptor antagonist SB-271046 reverses scopolamine-disrupted consolidation of a passive avoidance task and ameliorates spatial task deficits in aged rats. Neuropsychopharmacology 29:93-100. doi :10.1038/sj.npp.1300332

Frantz KJ, Hansson KJ, Stouffer DG, Parsons LH (2002) 5-HT(6) receptor antagonism potentiates the behavioral and neurochemical effects of amphetamine but not cocaine. Neuropharmacology 42:170-180

Geldenhuys WJ, Van der Schyf CJ (2009) The serotonin 5-HT6 receptor: a viable drug target for treating cognitive deficits in Alzheimer's disease. Expert Rev Neurother 9:1073-1085. doi:10.1586/ern.09.51

Goldsmith BA, Abrams TW (1992) cAMP modulates multiple $\mathrm{K}+$ currents, increasing spike duration and excitability in Aplysia sensory neurons. Proc Natl Acad Sci U S A 89:11481-11485

Grant KA, Barrett JE (1991) Blockade of the discriminative stimulus effects of ethanol with 5-HT3 receptor antagonists. Psychopharmacology 104:451-456

Harkany T, Dijkstra IM, Oosterink BJ et al (2000) Increased amyloid precursor protein expression and serotonergic sprouting following excitotoxic lesion of the rat magnocellular nucleus basalis: neuroprotection by $\mathrm{Ca}(2+)$ antagonist nimodipine. Neuroscience 101:101-114

Harkany T, Mulder J, Horvath KM, Keijser J, van der Meeberg EK, Nyakas C, Luiten PG (2001) Oral post-lesion administration of 5-HT(1A) receptor agonist repinotan hydrochloride (BAY $\mathrm{x}$ 3702) attenuates NMDA-induced delayed neuronal death in rat magnocellular nucleus basalis. Neuroscience 108:629-642

Hart AK, Fioravante D, Liu RY, Phares GA, Cleary LJ, Byrne JH (2011) Serotonin-mediated synapsin expression is necessary for long-term facilitation of the Aplysia sensorimotor synapse. J Neurosci 31:18401-18411. doi:10.1523/JNEURO SCI.2816-11.2011

Hensler JG (2002) Differential regulation of 5-HT1A receptor-G protein interactions in brain following chronic antidepressant administration. Neuropsychopharmacology 26:565-573. doi:10.1016/S0893-133X(01)00395-5

Herrmann AP, Lunardi P, Pilz LK et al (2012) Effects of the putative antipsychotic alstonine on glutamate uptake in acute hippocampal slices. Neurochem Int 61:1144-1150. doi:10.1016/j.neuint.2012.08.006

Hilgert M, Buchholzer M, Jeltsch H, Kelche C, Cassel JC, Klein J (2000) Serotonergic modulation of hippocampal acetylcholine release after long-term neuronal grafting. NeuroReport 11:3063-3065

Hodges H, Sowinski P, Sinden JD, Netto CA, Fletcher A (1995) The selective 5-HT3 receptor antagonist, WAY100289, enhances spatial memory in rats with ibotenate lesions of the forebrain cholinergic projection system. Psychopharmacology 117:318-332

Horiguchi M, Huang M, Meltzer HY (2011a) Interaction of mGlu2/3 agonism with clozapine and lurasidone to restore novel object recognition in subchronic phencyclidine-treated rats. Psychopharmacology 217:13-24. doi:10.1007/s00213-011-2251-2

Horiguchi M, Huang M, Meltzer HY (2011b) The role of 5-hydroxytryptamine 7 receptors in the phencyclidine-induced novel object recognition deficit in rats. J Pharmacol Exp Ther 338:605-614. doi:10.1124/jpet.111.180638

Hoyer D, Hannon JP, Martin GR (2002) Molecular, pharmacological and functional diversity of 5-HT receptors. Pharmacol Biochem Behav 71:533-554

Hu JY, Baussi O, Levine A, Chen Y, Schacher S (2011) Persistent long-term synaptic plasticity requires activation of a new signaling pathway by additional stimuli. J Neurosci $31: 8841-8850$. doi:10.1523/JNEUROSCI.1358-11.2011

Huang YY, Kandel ER (2007) 5-Hydroxytryptamine induces a protein kinase $\mathrm{A} /$ mitogen-activated protein kinase-mediated and macromolecular synthesis-dependent late phase of long-term potentiation in the amygdala. J Neurosci 27:3111-3119. doi:10.1523/JN EUROSCI.3908-06.2007

Imperato A, Angelucci L (1989) 5-HT3 receptors control dopamine release in the nucleus accumbens of freely moving rats. Neurosci Lett 101:214-217

Jiang LH, Ashby CR Jr, Kasser RJ, Wang RY (1990) The effect of intraventricular administration of the 5-HT3 receptor agonist 2-methylserotonin on the release of dopamine in the nucleus accumbens: an in vivo chronocoulometric study. Brain Res 513:156-160

Johnson BA, Ait-Daoud N, Elkashef AM et al (2008a) A preliminary randomized, double-blind, placebo-controlled study of the safety and efficacy of ondansetron in the treatment of methamphetamine dependence. Int J Neuropsychopharmacol 11:1-14. doi:10.1017/S1461145707007778

Johnson CN, Ahmed M, Miller ND (2008b) 5-HT6 receptor antagonists: prospects for the treatment of cognitive disorders including dementia. Curr Opin Drug Discov Devel 11:642-654

Ju Yeon B, Yeon Hee S (2005) Blockade of 5-HT(3) receptor with MDL 72222 and Y 25130 reduces beta-amyloid protein (25-35)-induced neurotoxicity in cultured rat cortical neurons. Eur J Pharmacol 520:12-21. doi:10.1016/j.ejphar.2005.07.021

Kagami Y, Shigenobu S, Watanabe S (1992) Neuroprotective effect of 5-HT3 receptor antagonist on ischemia-induced decrease in CA1 field potential in rat hippocampal slices. Eur J Pharmacol 224:51-56

Kalivas PW (1993) Neurotransmitter regulation of dopamine neurons in the ventral tegmental area. Brain Res Brain Res Rev $18: 75-113$ 
Kalivas PW, Duffy P, Barrow J (1989) Regulation of the mesocorticolimbic dopamine system by glutamic acid receptor subtypes. J Pharmacol Exp Ther 251:378-387

Kenakin T (1995) Agonist-receptor efficacy. II. Agonist trafficking of receptor signals. Trends Pharmacol Sci 16:232-238

Kendall I, Slotten HA, Codony X, Burgueno J, Pauwels PJ, Vela JM, Fone KC (2011) E-6801, a 5-HT6 receptor agonist, improves recognition memory by combined modulation of cholinergic and glutamatergic neurotransmission in the rat. Psychopharmacology 213:413-430. doi:10.1007/s00213-010-1854-3

Kia HK, Brisorgueil MJ, Daval G, Langlois X, Hamon M, Verge D (1996) Serotonin1A receptors are expressed by a subpopulation of cholinergic neurons in the rat medial septum and diagonal band of Broca-a double immunocytochemical study. Neuroscience 74:143-154

King MV, Sleight AJ, Woolley ML, Topham IA, Marsden CA, Fone KC (2004) 5-HT6 receptor antagonists reverse delaydependent deficits in novel object discrimination by enhancing consolidation-an effect sensitive to NMDA receptor antagonism. Neuropharmacology 47:195-204. doi:10.1016/j.neuroph arm.2004.03.012

Kiser D, Steemers B, Branchi I, Homberg JR (2012) The reciprocal interaction between serotonin and social behaviour. Neurosci Biobehav Rev 36:786-798. doi:10.1016/j.neubiorev.2011.12.009

Koenig J, Lecourtier L, Cosquer B, Pereira PM, Cassel JC (2011) Spatial memory alterations by activation of septal 5HT 1A receptors: no implication of cholinergic septohippocampal neurons. Psychopharmacology 214:437-454. doi:10.1007/ s00213-010-2049-7

Kranz GS, Kasper S, Lanzenberger R (2010) Reward and the serotonergic system. Neuroscience 166:1023-1035. doi:10.1016/j. neuroscience.2010.01.036

Lee YS, Choi SL, Lee SH et al (2009) Identification of a serotonin receptor coupled to adenylyl cyclase involved in learningrelated heterosynaptic facilitation in Aplysia. Proc Natl Acad Sci U S A 106:14634-14639. doi:10.1073/pnas.0907502106

Lelong V, Lhonneur L, Dauphin F, Boulouard M (2003) BIMU 1 and RS 67333, two 5-HT4 receptor agonists, modulate spontaneous alternation deficits induced by scopolamine in the mouse. Naunyn Schmiedebergs Arch Pharmacol 367:621-628. doi:10.1007/ s00210-003-0743-2

Lesch KP, Waider J (2012) Serotonin in the modulation of neural plasticity and networks: implications for neurodevelopmental disorders. Neuron 76:175-191. doi:10.1016/j.neuron.2012.09.013

Levallet G, Hotte M, Boulouard M, Dauphin F (2009) Increased particulate phosphodiesterase 4 in the prefrontal cortex supports 5-HT4 receptor-induced improvement of object recognition memory in the rat. Psychopharmacology 202:125-139. doi: $10.1007 / \mathrm{s} 00213-008-1283-8$

Lezoualc'h F (2007) 5-HT4 receptor and Alzheimer's disease: the amyloid connection. Exp Neurol 205:325-329. doi:10.1016/j.expneurol.2007.02.001

Li Q, Muma NA, Battaglia G, Van de Kar LD (1997) A desensitization of hypothalamic 5-HT1A receptors by repeated injections of paroxetine: reduction in the levels of $\mathrm{G}(\mathrm{i})$ and $\mathrm{G}(\mathrm{o})$ proteins and neuroendocrine responses, but not in the density of 5-HT1A receptors. J Pharmacol Exp Ther 282:1581-1590

Llado-Pelfort L, Santana N, Ghisi V, Artigas F, Celada P (2012) 5-HT1A receptor agonists enhance pyramidal cell firing in prefrontal cortex through a preferential action on GABA interneurons. Cereb Cortex 22:1487-1497. doi:10.1093/cercor/bhr220

Madsen K, Neumann WJ, Holst K et al (2011) Cerebral serotonin 4 receptors and amyloid-beta in early Alzheimer's disease. J Alzheimers Dis 26:457-466. doi:10.3233/JAD-2011-110056
Mannoury la Cour C, El Mestikawy S, Hanoun N, Hamon M, Lanfumey L (2006) Regional differences in the coupling of 5-hydroxytryptamine-1A receptors to $\mathrm{G}$ proteins in the rat brain. Mol Pharmacol 70:1013-1021. doi:10.1124/mol.106.022756

Manuel-Apolinar L, Meneses A (2004) 8-OH-DPAT facilitated memory consolidation and increased hippocampal and cortical cAMP production. Behav Brain Res 148:179-184

Marcos B, Gil-Bea FJ, Hirst WD, Garcia-Alloza M, Ramirez MJ (2006) Lack of localization of 5-HT6 receptors on cholinergic neurons: implication of multiple neurotransmitter systems in 5-HT6 receptor-mediated acetylcholine release. Eur J Neurosci 24:1299-1306. doi:10.1111/j.1460-9568.2006.05003.x

Maricq AV, Peterson AS, Brake AJ, Myers RM, Julius D (1991) Primary structure and functional expression of the 5HT3 receptor, a serotonin-gated ion channel. Science 254:432-437

Marsden CA, King MV, Fone KC (2011) Influence of social isolation in the rat on serotonergic function and memory-relevance to models of schizophrenia and the role of 5-HT(6) receptors. Neuropharmacology 61:400-407. doi:10.1016/j.neuroph arm.2011.03.003

Martin KC, Michael D, Rose JC, Barad M, Casadio A, Zhu H, Kandel ER (1997) MAP kinase translocates into the nucleus of the presynaptic cell and is required for long-term facilitation in Aplysia. Neuron 18:899-912

Matsumoto M, Togashi H, Mori K, Ueno K, Ohashi S, Kojima T, Yoshioka M (2001) Evidence for involvement of central 5-HT(4) receptors in cholinergic function associated with cognitive processes: behavioral, electrophysiological, and neurochemical studies. J Pharmacol Exp Ther 296:676-682

Matsuno K, Senda T, Matsunaga K, Mita S, Kaneto H (1993) Similar ameliorating effects of benzomorphans and 5-HT2 antagonists on drug-induced impairment of passive avoidance response in mice: comparison with acetylcholinesterase inhibitors. Psychopharmacology 112:134-141

McLean JH, Smith A, Rogers S, Clarke K, Darby-King A, Harley CW (2009) A phosphodiesterase inhibitor, cilomilast, enhances cAMP activity to restore conditioned odor preference memory after serotonergic depletion in the neonate rat. Neurobiol Learn Mem 92:63-69. doi:10.1016/j.nlm.2009.02.003

McMahon LR, Cunningham KA (1999) Antagonism of 5-hydroxytryptamine(4) receptors attenuates hyperactivity induced by cocaine: putative role for 5-hydroxytryptamine(4) receptors in the nucleus accumbens shell. J Pharmacol Exp Ther 291:300-307

Meltzer HY, Massey BW, Horiguchi M (2012) Serotonin receptors as targets for drugs useful to treat psychosis and cognitive impairment in schizophrenia. Curr Pharm Biotechnol 13:1572-1586

Meneses A (2004) Effects of the 5-HT7 receptor antagonists SB-269970 and DR 4004 in autoshaping Pavlovian/instrumental learning task. Behav Brain Res 155:275-282. doi:10.1016/j.bbr.2004.04.026

Misane I, Ogren SO (2003) Selective 5-HT1A antagonists WAY 100635 and NAD-299 attenuate the impairment of passive avoidance caused by scopolamine in the rat. Neuropsychopharmacology 28:253-264. doi:10.1038/sj.npp.1300024

Mitchell ES, Neumaier JF (2005) 5-HT6 receptors: a novel target for cognitive enhancement. Pharmacol Ther 108:320-333. doi:10.1016/j.pharmthera.2005.05.001

Morales M, Wang SD, Diaz-Ruiz O, Jho DH (2004) Cannabinoid CB1 receptor and serotonin 3 receptor subunit A (5-HT3A) are co-expressed in GABA neurons in the rat telencephalon. $\mathbf{J}$ Comp Neurol 468:205-216. doi:10.1002/cne.10968

Mori K, Togashi H, Kojima T, Matsumoto M, Ohashi S, Ueno K, Yoshioka M (2001) Different effects of anxiolytic agents, diazepam and 5-HT(1A) agonist tandospirone, on hippocampal 
long-term potentiation in vivo. Pharmacol Biochem Behav 69:367-372

Moser PC, Bergis OE, Jegham S et al (2002) SL65.0155, a novel 5-hydroxytryptamine(4) receptor partial agonist with potent cognition-enhancing properties. J Pharmacol Exp Ther 302:731-741. doi:10.1124/jpet.102.034249

Navailles S, De Deurwaerdere P, Porras G, Spampinato U (2004) In vivo evidence that 5-HT2C receptor antagonist but not agonist modulates cocaine-induced dopamine outflow in the rat nucleus accumbens and striatum. Neuropsychopharmacology 29:319326. doi:10.1038/sj.npp.1300329

Neisewander JL, Acosta JI (2007) Stimulation of 5-HT2C receptors attenuates cue and cocaine-primed reinstatement of cocaineseeking behavior in rats. Behav Pharmacol 18:791-800. doi:10. 1097/FBP.0b013e3282f1c94b

Nic Dhonnchadha BA, Cunningham KA (2008) Serotonergic mechanisms in addiction-related memories. Behav Brain Res 195:3953. doi:10.1016/j.bbr.2008.06.026

Nic Dhonnchadha BA, Fox RG, Stutz SJ, Rice KC, Cunningham KA (2009) Blockade of the serotonin 5-HT2A receptor suppresses cue-evoked reinstatement of cocaine-seeking behavior in a rat self-administration model. Behav Neurosci 123:382-396. doi:10.1037/a0014592

Nitsch RM, Deng M, Growdon JH, Wurtman RJ (1996) Serotonin 5-HT2a and 5-HT2c receptors stimulate amyloid precursor protein ectodomain secretion. J Biol Chem 271:4188-4194

Noristani HN, Verkhratsky A, Rodriguez JJ (2012) High tryptophan diet reduces CA1 intraneuronal beta-amyloid in the triple transgenic mouse model of Alzheimer's disease. Aging Cell 11:810 822. doi:10.1111/j.1474-9726.2012.00845.x

O'Dell LE, Parsons LH (2004) Serotonin1B receptors in the ventral tegmental area modulate cocaine-induced increases in nucleus accumbens dopamine levels. J Pharmacol Exp Ther 311:711719. doi:10.1124/jpet.104.069278

Ohno M, Watanabe S (1996) Blockade of 5-HT1A receptors compensates loss of hippocampal cholinergic neurotransmission involved in working memory of rats. Brain Res 736:180-188

Ohno M, Watanabe S (1997) Differential effects of 5-HT3 receptor antagonism on working memory failure due to deficiency of hippocampal cholinergic and glutamatergic transmission in rats. Brain Res 762:211-215

Pakaski M, Bjelik A, Hugyecz M, Kasa P, Janka Z, Kalman J (2005) Imipramine and citalopram facilitate amyloid precursor protein secretion in vitro. Neurochem Int 47:190-195. doi:10.1016/j.neuint.2005.03.004

Pandya AA, Yakel JL (2013) Activation of the alpha7 nicotinic ACh receptor induces anxiogenic effects in rats which is blocked by a 5-HT(1)a receptor antagonist. Neuropharmacology 70:35-42. doi:10.1016/j.neuropharm.2013.01.004

Paris JM, Cunningham KA (1991) Serotonin 5-HT3 antagonists do not alter the discriminative stimulus properties of cocaine. Psychopharmacology 104:475-478

Park SM, Williams CL (2012) Contribution of serotonin type 3 receptors in the successful extinction of cued or contextual fear conditioned responses: interactions with GABAergic signaling. Rev Neurosci 23:555-569. doi:10.1515/revneuro-2012-0052

Parsons LH, Weiss F, Koob GF (1998) Serotonin1B receptor stimulation enhances cocaine reinforcement. J Neurosci 18:10078-10089

Payton S, Cahill CM, Randall JD, Gullans SR, Rogers JT (2003) Drug discovery targeted to the Alzheimer's APP mRNA 5'-untranslated region: the action of paroxetine and dimercaptopropanol. J Mol Neurosci 20:267-275. doi:10.1385/jmn:20: $3: 267$

Pei Q, Zetterstrom T, Leslie RA, Grahame-Smith DG (1993) 5-HT3 receptor antagonists inhibit morphine-induced stimulation of mesolimbic dopamine release and function in the rat. Eur $\mathbf{J}$ Pharmacol 230:63-68

Perez-Garcia GS, Meneses A (2005) Effects of the potential 5-HT7 receptor agonist AS 19 in an autoshaping learning task. Behav Brain Res 163:136-140. doi:10.1016/j.bbr.2005.04.014

Perez-Garcia G, Meneses A (2008a) Ex vivo study of 5-HT(1A) and 5-HT(7) receptor agonists and antagonists on cAMP accumulation during memory formation and amnesia. Behav Brain Res 195:139-146. doi:10.1016/j.bbr.2008.07.033

Perez-Garcia G, Meneses A (2008b) Memory formation, amnesia, improved memory and reversed amnesia: 5-HT role. Behav Brain Res 195:17-29. doi:10.1016/j.bbr.2007.11.027

Pitsikas N, Rigamonti AE, Cella SG, Muller EE (2003) The 5-HT 1A receptor antagonist WAY 100635 improves rats performance in different models of amnesia evaluated by the object recognition task. Brain Res 983:215-222

Pitsikas N, Zisopoulou S, Pappas I, Sakellaridis N (2008) The selective 5-HT(6) receptor antagonist Ro 04-6790 attenuates psychotomimetic effects of the NMDA receptor antagonist MK-801. Behav Brain Res 188:304-309. doi:10.1016/j.bbr.2007.11.010

Polter AM, Li X (2010) 5-HT1A receptor-regulated signal transduction pathways in brain. Cell Signal 22:1406-1412. doi:10.1016/j.cellsig.2010.03.019

Porras G, Di Matteo V, De Deurwaerdere P, Esposito E, Spampinato U (2002) Central serotonin 4 receptors selectively regulate the impulse-dependent exocytosis of dopamine in the rat striatum: in vivo studies with morphine, amphetamine and cocaine. Neuropharmacology 43:1099-1109

Postina R (2012) Activation of alpha-secretase cleavage. J Neurochem 120(Suppl 1):46-54. doi:10.1111/j.1471-4159.2011.07459.x

Price TL, Darby-King A, Harley CW, McLean JH (1998) Serotonin plays a permissive role in conditioned olfactory learning induced by norepinephrine in the neonate rat. Behav Neurosci 112:1430-1437

Pytliak M, Vargova V, Mechirova V, Felsoci M (2011) Serotonin receptors - from molecular biology to clinical applications. Physiol Res 60:15-25

Raap DK, Evans S, Garcia F et al (1999) Daily injections of fluoxetine induce dose-dependent desensitization of hypothalamic 5-HT1A receptors: reductions in neuroendocrine responses to 8-OH-DPAT and in levels of Gz and Gi proteins. J Pharmacol Exp Ther 288:98-106

Rahimian R, Fakhfouri G, Ejtemaei Mehr S et al (2013) Tropisetron attenuates amyloid-beta-induced inflammatory and apoptotic responses in rats. Eur J Clin Invest 43:1039-1051. doi:10.1111/eci.12141

Richter-Levin G, Segal M (1989) Raphe cells grafted into the hippocampus can ameliorate spatial memory deficits in rats with combined serotonergic/cholinergic deficiencies. Brain Res 478:184-186

Robert SJ, Zugaza JL, Fischmeister R, Gardier AM, Lezoualc'h F (2001) The human serotonin 5-HT4 receptor regulates secretion of non-amyloidogenic precursor protein. J Biol Chem 276:44881-44888. doi:10.1074/jbc.M109008200

Robert S, Maillet M, Morel E, Launay JM, Fischmeister R, Mercken L, Lezoualc'h F (2005) Regulation of the amyloid precursor protein ectodomain shedding by the 5-HT4 receptor and Epac. FEBS Lett 579:1136-1142. doi:10.1016/j.febslet.2005.01.010

Rodd-Henricks ZA, McKinzie DL, Melendez RI, Berry N, Murphy JM, McBride WJ (2003) Effects of serotonin-3 receptor antagonists on the intracranial self-administration of ethanol within the ventral tegmental area of Wistar rats. Psychopharmacology 165:252-259. doi: 10.1007/s00213-002-1300-2

Rodriguez JJ, Noristani HN, Verkhratsky A (2012) The serotonergic system in ageing and Alzheimer's disease. Prog Neurobiol 99:15-41. doi:10.1016/j.pneurobio.2012.06.010 
Rozas C, Loyola S, Ugarte G et al (2012) Acutely applied MDMA enhances long-term potentiation in rat hippocampus involving D1/D5 and 5-HT2 receptors through a polysynaptic mechanism. Eur Neuropsychopharmacol 22:584-595. doi:10.1016/j.euroneuro.2011.11.010

Rutten K, Lieben C, Smits L, Blokland A (2007a) The PDE4 inhibitor rolipram reverses object memory impairment induced by acute tryptophan depletion in the rat. Psychopharmacology 192:275282. doi:10.1007/s00213-006-0697-4

Rutten K, Prickaerts J, Hendrix M, van der Staay FJ, Sik A, Blokland A (2007b) Time-dependent involvement of cAMP and cGMP in consolidation of object memory: studies using selective phosphodiesterase type 2, 4 and 5 inhibitors. Eur J Pharmacol 558:107-112. doi:10.1016/j.ejphar.2006.11.041

Sacktor TC, Kruger KE, Schwartz JH (1988) Activation of protein kinase $\mathrm{C}$ by serotonin: biochemical evidence that it participates in the mechanisms underlying facilitation in Aplysia. J Physiol (Paris) 83:224-231

Santana N, Bortolozzi A, Serrats J, Mengod G, Artigas F (2004) Expression of serotonin $1 \mathrm{~A}$ and serotonin $2 \mathrm{~A}$ receptors in pyramidal and GABAergic neurons of the rat prefrontal cortex. Cereb Cortex 14:1100-1109. doi:10.1093/cercor/bhh070

Santana N, Mengod G, Artigas F (2009) Quantitative analysis of the expression of dopamine D1 and D2 receptors in pyramidal and GABAergic neurons of the rat prefrontal cortex. Cereb Cortex 19:849-860. doi:10.1093/cercor/bhn134

Schiapparelli L, Del Rio J, Frechilla D (2005) Serotonin 5-HT receptor blockade enhances $\mathrm{Ca}(2+) /$ calmodulin-dependent protein kinase II function and membrane expression of AMPA receptor subunits in the rat hippocampus: implications for memory formation. $\mathbf{J}$ Neurochem 94:884-895. doi:10.1111/j.1471-4159.2005.03193.x

Schilstrom B, Konradsson-Geuken A, Ivanov V et al (2011) Effects of S-citalopram, citalopram, and R-citalopram on the firing patterns of dopamine neurons in the ventral tegmental area, $\mathrm{N}$-methyl-D-aspartate receptor-mediated transmission in the medial prefrontal cortex and cognitive function in the rat. Synapse 65:357-367. doi:10.1002/syn.20853

Segu L, Lecomte MJ, Wolff M et al (2010) Hyperfunction of muscarinic receptor maintains long-term memory in 5-HT4 receptor knock-out mice. PLoS ONE 5:e9529. doi:10.1371/ journal.pone.0009529

Siniscalchi A, Badini I, Beani L, Bianchi C (1999) 5-HT4 receptor modulation of acetylcholine outflow in guinea pig brain slices. NeuroReport 10:547-551

Soria-Fregozo C, Flores-Soto ME, Perez-Vega MI, Feria-Velasco A (2013) 5-HT denervation of the adult rat prefrontal cortex induces changes in the expression of alpha4 and alpha7 nicotinic acetylcholine receptor subtypes. Neurologia 28:212-218. doi:10.1016/j.nrl.2012.04.002

Staubli U, Xu FB (1995) Effects of 5-HT3 receptor antagonism on hippocampal theta rhythm, memory, and LTP induction in the freely moving rat. J Neurosci 15:2445-2452

Takumi Y, Bergersen L, Landsend AS, Rinvik E, Ottersen OP (1998) Synaptic arrangement of glutamate receptors. Prog Brain Res 116:105-121

Terry AV Jr, Buccafusco JJ, Prendergast MA et al (1996) The 5-HT3 receptor antagonist, RS-56812, enhances delayed matching performance in monkeys. NeuroReport 8:49-54

Tottori K, Nakai M, Uwahodo Y et al (2002) Attenuation of scopolamine-induced and age-associated memory impairments by the sigma and 5-hydroxytryptamine(1A) receptor agonist OPC14523 (1-[3-[4-(3-chlorophenyl)-1-piperazinyl]propyl]-5-methoxy-3,4-dihydro-2[1H]-quino linone monomethanesulfonate). J Pharmacol Exp Ther 301:249-257

Toyohara J, Hashimoto K (2010) alpha7 Nicotinic Receptor Agonists: Potential Therapeutic Drugs for Treatment of Cognitive
Impairments in Schizophrenia and Alzheimer's Disease. Open Med Chem J 4:37-56. doi:10.2174/1874104501004010037

Upadhya SC, Smith TK, Hegde AN (2004) Ubiquitin-proteasome-mediated CREB repressor degradation during induction of long-term facilitation. J Neurochem 91:210-219. doi:10.1111/j.1471-4159.2004.02707.x

Upton N, Chuang TT, Hunter AJ, Virley DJ (2008) 5-HT6 receptor antagonists as novel cognitive enhancing agents for Alzheimer's disease. Neurotherapeutics 5:458-469. doi:10.1016/j.nurt.2008.05.008

Valentini V, Piras G, De Luca MA et al (2013) Evidence for a role of a dopamine/5-HT6 receptor interaction in cocaine reinforcement. Neuropharmacology 65:58-64. doi:10.1016/j.neuroph arm.2012.08.025

van Donkelaar EL, Rutten K, Blokland A, Akkerman S, Steinbusch HW, Prickaerts J (2008) Phosphodiesterase 2 and 5 inhibition attenuates the object memory deficit induced by acute tryptophan depletion. Eur J Pharmacol 600:98-104. doi:10.1016/j.ejphar.2008.10.027

van Gaalen MM, Schetters D, Schoffelmeer AN, De Vries TJ (2010) 5-HT6 antagonism attenuates cue-induced relapse to cocaine seeking without affecting cocaine reinforcement. Int J Neuropsychopharmacol 13:961-965. doi:10.1017/ S1461145710000428

Verdurand M, Berod A, Le Bars D, Zimmer L (2011) Effects of amyloid-beta peptides on the serotoninergic 5-HT1A receptors in the rat hippocampus. Neurobiol Aging 32:103-114. doi:10.1016/j.neurobiolaging.2009.01.008

Waider J, Proft F, Langlhofer G, Asan E, Lesch KP, Gutknecht L (2013) GABA concentration and GABAergic neuron populations in limbic areas are differentially altered by brain serotonin deficiency in Tph2 knockout mice. Histochem Cell Biol 139:267-281. doi:10.1007/s00418-012-1029-x

Wang RY, Arvanov VL (1998) M100907, a highly selective 5-HT2A receptor antagonist and a potential atypical antipsychotic drug, facilitates induction of long-term potentiation in area CA1 of the rat hippocampal slice. Brain Res 779:309-313

West PJ, Marcy VR, Marino MJ, Schaffhauser H (2009) Activation of the 5-HT(6) receptor attenuates long-term potentiation and facilitates GABAergic neurotransmission in rat hippocampus. Neuroscience 164:692-701. doi:10.1016/j. neuroscience.2009.07.061

Wise RA, Rompre PP (1989) Brain dopamine and reward. Annu Rev Psychol 40:191-225. doi:10.1146/annurev. ps.40.020189.001203

Woods S, Clarke NN, Layfield R, Fone KC (2012) 5-HT(6) receptor agonists and antagonists enhance learning and memory in a conditioned emotion response paradigm by modulation of cholinergic and glutamatergic mechanisms. $\mathrm{Br} \mathrm{J}$ Pharmacol 167:436-449. doi:10.1111/j.1476-5381.2012.02022.x

Woolley ML, Marsden CA, Sleight AJ, Fone KC (2003) Reversal of a cholinergic-induced deficit in a rodent model of recognition memory by the selective 5-HT6 receptor antagonist, Ro 04-6790. Psychopharmacology 170:358-367. doi:10.1007/ s00213-003-1552-5

Woolley ML, Marsden CA, Fone KC (2004) 5-ht6 receptors. Curr Drug Targets CNS Neurol Disord 3:59-79

Yuan Q, Harley CW, Bruce JC, Darby-King A, McLean JH (2000) Isoproterenol increases CREB phosphorylation and olfactory nerve-evoked potentials in normal and 5-HT-depleted olfactory bulbs in rat pups only at doses that produce odor preference learning. Learn Mem 7:413-421

Yuan Q, Harley CW, McLean JH (2003) Mitral cell beta1 and 5-HT2A receptor colocalization and cAMP coregulation: a new model of norepinephrine-induced learning in the olfactory bulb. Learn Mem 10:5-15. doi:10.1101/lm.54803 